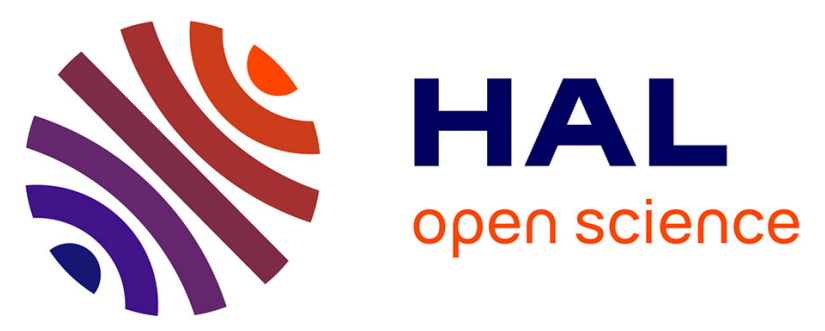

\title{
First Triassic palaeomagnetic constraints from Junggar (NW China) and their implications for the Mesozoic tectonics in Central Asia
}

Flavien Choulet, Yan Chen, Jean-Pascal Cogné, Aurélien Rabillard, Bo Wang, Wei Lin, Michel Faure, Dominique Cluzel

\section{To cite this version:}

Flavien Choulet, Yan Chen, Jean-Pascal Cogné, Aurélien Rabillard, Bo Wang, et al.. First Triassic palaeomagnetic constraints from Junggar (NW China) and their implications for the Mesozoic tectonics in Central Asia. Journal of Southeast Asian earth sciences, 2013, 78, pp.371-394. 10.1016/j.jseaes.2013.01.023 . insu-00796917

\section{HAL Id: insu-00796917 https://hal-insu.archives-ouvertes.fr/insu-00796917}

Submitted on 6 Mar 2013

HAL is a multi-disciplinary open access archive for the deposit and dissemination of scientific research documents, whether they are published or not. The documents may come from teaching and research institutions in France or abroad, or from public or private research centers.
L'archive ouverte pluridisciplinaire HAL, est destinée au dépôt et à la diffusion de documents scientifiques de niveau recherche, publiés ou non, émanant des établissements d'enseignement et de recherche français ou étrangers, des laboratoires publics ou privés. 
First Triassic palaeomagnetic constraints from Junggar (NW China) and their implications for the Mesozoic tectonics in Central Asia

Flavien Choulet ${ }^{1, *}$, Yan Chen ${ }^{1}$, Jean-Pascal Cogné ${ }^{2}$, Aurélien Rabillard ${ }^{1}$, Bo Wang ${ }^{3}$, Wei Lin ${ }^{4}$, Michel Faure $^{1}$, Dominique Cluzel ${ }^{5}$

${ }^{1}$ : Institut des Sciences de la Terre d'Orléans, UMR 7327 - CNRS/Université d'Orléans, 1A, rue de la Férollerie, 45071 Orléans Cedex 2

2: Institut de Physique du Globe de Paris, 1, rue Jussieu, 75238 Paris Cedex 5

3. Department of Earth Sciences, Nanjing University, Nanjing, China

4: State Key Laboratory of Lithospheric Evolution, Institute of Geology and Geophysics, Chinese Academy of Sciences, P.O. Box 9825, Beijing 100029, China

5: Pôle Pluri-disciplinaire de la Matière et de l'Environnement-EA 3325, Université de la NouvelleCalédonie, BP R4, 98851 Noumea cedex, New Caledonia

* : corresponding author - flavien.choulet@univ-orleans.fr

Keywords: Palaeomagnetism, Junggar, Transcurrent tectonics, Triassic, reactivation

Abstract

Northwestern China belts result from the Palaeozoic collage of Central Asia and the subsequent reactivations due to far-field effects of the Mesozoic Tibetan and the Cenozoic Himalayan collisions. Triassic is a crucial period to understand and decipher the tectonics related to these two episodes. About 250 oriented palaeomagnetic cores from 43 sites were collected from six sections of Upper Permian to Late Triassic sandstone, in South and West Junggar, Northwestern China. Thermomagnetic, IRM and hysteresis measurements reveal magnetite as the main carrier of the 
magnetic remanence with minor hematite and maghemite. Stepwise thermal demagnetisation has generally isolated two components. The low temperature component, up to $300-350^{\circ} \mathrm{C}$, displays a direction consistent with the present-day geomagnetic field. The locality-mean directions related to the high temperature component (above $350^{\circ} \mathrm{C}$ ) were also calculated. Two out of six sections display intense viscous magnetisation and the occurrence of maghemite reveals a possible Cenozoic chemical remagnetisation for these two localities. For the other four localities, we assume that the magnetisation is primary because: 1) AMS measurements reveal a primary fabric, 2) there are local occurrences of antipodal polarities, and 3) palaeolatitudes of tilt-corrected poles are compatible with previous studies. The consistency between the Early Triassic poles of West and South Junggar indicates that Junggar evolved as a rigid block only since Early Mesozoic. The comparison of the Late Palaeozoic and the Early Mesozoic poles of Junggar and those of Siberia and Tarim shows major rotations between the Late Permian and the Late Jurassic-Early Cretaceous. These periods of discrete rotations are characterized by strike-slip faulting in Tianshan and Altai and they may correlate with the major episodes of coarse-grained detrital sedimentation and uplift of the range. Especially, the counterclockwise rotations of Junggar relative to Tarim and Siberia, which occurred between the Early and the Late Triassic and between the Late Triassic and the Late Jurassic, are accommodated by transpressive tectonics in the Tianshan and the Altai belts. This reactivation is a far-field effect of Tibetan blocks diachronous collisions. Therefore, these first Triassic palaeomagnetic results from Junggar infer that post-Carboniferous rotations were due to the combined effect of the post-orogenic transcurrent movement and the Mesozoic oblique reactivation.

\section{Introduction}

The present structures in Central Asia are due to the combined effect of the Palaeozoic orogenic collage and the subsequent reactivations. This Palaeozoic collage, namely the Altaids, was formed by the amalgamation of the Baltica, the Siberia and the Tarim cratons. A single long-lived subduction was initially proposed to account for the linear pattern of Central Asia units (Sengör et al., 
1993; Sengör and Natal'in, 1996). This model also emphasizes the role of Late Palaeozoic strike-slip faults that shredded the original collage to give its current disturbed geometry (Sengör et al., 1993). Although several recent studies throughout the Altaids rather support a polycyclic collage than a single-phase model (Fillipova et al., 2001; Badarch et al., 2002; Xiao et al., 2004; Charvet et al., 2007; Degtyarev, 2011), the Late Palaeozoic transcurrent event was largely documented (Yin \& Nie, 1996; Laurent-Charvet et al., 2002; 2003; Buslov et al., 2004; Wang et al., 2007). Syn-kinematic granites and mylonitic rocks attest for a ductile deformation localized along the major strike-slip shear zones in Altai (Laurent-Charvet et al., 2002; Buslov et al., 2004) or Tianshan (Yin \& Nie, 1996; de Jong et al., 2009; Wang et al., 2009a). Ar-Ar dating on micas from the mylonitic rocks constrains ductile shearing between $305 \mathrm{Ma}$ and 245 Ma (Melnikov et al., 1997, 1998; Vladimirov et al., 1998; Travin et al., 2001; Zhou et al., 2001; Laurent-Charvet et al., 2003; de Jong et al., 2009; Wang et al., 2009a); late brittle faulting along these shear zones is not well documented, though. Recent palaeomagnetic studies have intended to estimate the importance of these Late Palaeozoic displacements, in Northwestern China. Firstly, Wang et al. (2007) pointed out significant Permian rotations of Junggar with respect to Siberia and Tarim, accommodated by displacements up to several hundreds of kilometres along Altai and Tianshan strike-slip faults considering the Junggar as a rigid block. However, the existence of a rigid Junggar block was challenged by new palaeomagnetic collections from West and South Junggar (Choulet et al., 2011) that display significant differences of declination and inclination between these two areas in the Late Permian. The amount of displacements along the shear zones was also reevaluated with significant rotations occurring rather after the Late Permian than during the Permian (Choulet et al., 2011). The origin of these movements remains an open question.

The reactivation of the Central Asian belts was long recognized, especially in Tianshan (e.g. Molnar and Tapponnier, 1975; 1977). Folds and thrusts affect its northern and southern foreland. The major deformation event during Cenozoic (45-40 Ma) is interpreted as a far-field effect of the IndiaAsia collision (Molnar and Tapponnier, 1975, 1977; Avouac et al., 1993). Other minor reactivations, occurring during the Mesozoic time, were documented by the coarse and chaotic intercalations within the sedimentary record of the foreland (Hendrix et al., 1992; Hendrix, 2000; Li et al., 2004). 
Specifically, the huge conglomerate layers attest for episodic reactivations related to the Late Triassic (230-200 Ma), the Late Jurassic-Early Cretaceous (140-125 Ma) and the Late Cretaceous (80-70 Ma) successive collisions along the southern margin of Asia (Enkin et al., 1992; Yin \& Harrison, 2000). Folds and thrusts accommodate the deformation, but a significant transcurrent component is also emphasised (Hendrix et al., 1992). From the relationships between the Palaeozoic basement and its sedimentary cover, a Mesozoic palaeorelief was inferred in Tianshan, arguing for contemporaneous tectonics (Hendrix, 2000; Chen et al., 2011) and basement exhumation (Dumitru et al., 2001; Jolivet et al., 2010; Wang et al., 2009b).

In addition, the Late Jurassic to Early Cretaceous poles of Junggar and Tarim are statistically compatible, indicating that no statistically significant rotation or shortening has occurred since that time (Chen et al., 1991). However, Choulet et al. (2011) have shown significant rotations of Junggar with respect to Siberia and Tarim after the Late Permian. Therefore, the Triassic is a crucial period for understanding the interactions between the late-orogenic transcurrent movements and the Mesozoic reactivations, but very few data are available up to now. Hence, we have collected six sections of Late Permian to Late Triassic sedimentary rocks in West and South Junggar, aiming at estimating the Triassic displacements related to the post-orogenic transcurrent motions and the reactivations with palaeomagnetic tools.

\section{Geological setting}

\section{2.i. Northwestern China}

Northwestern China is a part of the Central Asian Orogenic Belt (CAOB), namely the Altaids (Fig. 1a). In Central Asia, this huge belt that developed from the Urals to the Pacific Ocean results from the amalgamation of the Baltica, the Siberia and the Tarim cratons during Palaeozoic. Single subduction (Sengör et al., 1993; Sengör and Natal'in, 1996) and polycyclic models (Filippova et al., 2001; Xiao et al., 2010) have been proposed to explain the linear pattern of the Central Asia units. 
In Northwestern China, the linearly trending Tianshan is the major structure that extends to Beishan to the east (Fig. 1b). To the west, the belt enlarges and contours the triangular-shaped Yili block, which represents a fragment of the Kazakhstan microcontinent (Wang et al., 2006, 2011). Two sedimentary basins with a Palaeozoic to Quaternary infilling bound the Tianshan range: the Junggar basin to the north and the Tarim basin to the south. The Tianshan range can be separated into three parts. The southern and central Tianshan consist of a Precambrian basement similar to Tarim, ophiolitic mélange and magmatic arc series (Charvet et al., 2007). Although the evolution of Palaeozoic Tianshan is largely debated (e.g. Gao et al., 1998; Xiao et al., 2008), a model including south-directed subductions of two separate oceanic domains and mid-Carboniferous collision has been proposed (e.g. Charvet et al., 2007; 2011). Conversely, North Tianshan is composed of a magmatic arc, an ophiolitic mélange, and associated turbidites. A Devonian to Carboniferous south-directed subduction is inferred (Wang et al., 2006). This subduction zone extends to the Kazakhstan, and its strike has been clockwise rotated up to $180^{\circ}$ in Kazakhstan and West Junggar (Fig. 1a). This bend structure represents the Kazakh orocline (Abrajevitch et al., 2007, 2008).

The northernmost units belong to the NW-SE striking Mongolian Fold Belt and the Altai-Sayan Belts (Fig. 1b). These units consist of Palaeozoic magmatic arc rocks, turbidites and ophiolitic mélanges (Windley et al., 2002; Xiao et al., 2004); microcontinents with metamorphic rocks are also recognized in the Altai Mountains. A polycyclic evolution with multiple subductions is proposed for the Mongolian Fold Belt, Chinese Altai and Altay-Sayan (Buslov et al., 2001; Xiao et al., 2004, 2009). 2.ii. North Tianshan

North Tianshan corresponds to the northern piedmont of the range; it is also referred as South Junggar (Fig. 2a). Basement units of the Borohoro Range (western part) consist of volcanic rocks related to a Devonian to Carboniferous arc (Wang et al., 2009a), folded turbidites (Wang et al., 2006), and an ophiolitic mélange (Wu \& Liu, 1989). To the east, at the northern piedmont of Bogda Range, the ophiolitic mélange is hidden, but sedimentary and volcanic rocks are similarly associated (Charvet et al., 2007). 
Late Carboniferous to Permian detrital rocks crop out near Urumqi city (Fig. 2a). Despite a regional variability of the Permian stratigraphy (Wartes et al., 2002), these thick sequences of clastic deposits (Carroll et al., 1995) represent a molasse that postdates the Carboniferous deformation (Charvet et al., 2007). Contemporaneously, dextral strike-slip faulting along major shear zones (Allen \& Vincent, 1997; Laurent-Charvet et al., 2002; 2003; Wang et al., 2009a) has generated pull-apart basin (Wang et al., 2009a), with bimodal alkaline magmatism (Shu et al., 2011).

The filling of the Junggar basin is marked by several kilometres of continental clastic deposits that underline high sedimentation rates (Chen et al., 2011). Timing and style of the deposition are relatively homogenous within the Junggar basin and similar to those of the Turfan-Hami and Tarim basins (Hendrix et al., 1992). The Triassic fluvial deposits consist of red sandstone at the base and at the top, with a thick intermediate conglomerate. Triassic is often hidden below the thick Lower Jurassic well-sorted clast-supported conglomerate (1000 metres), which becomes progressively finer and grades into the Middle Jurassic coal-rich sandstones (Hendrix et al., 1992). The Upper Jurassic consists of fine red beds, but the transition between the Jurassic and the Cretaceous is marked by a thick sedimentary breccia that can reach up to $800 \mathrm{~m}$ (Chen et al., 2011). Fine-grained fluvial to lacustrine sedimentation characterizes the Lower Cretaceous, but unconformable coarse-grained clastic rocks mark the Upper Cretaceous (Hendrix et al., 1992). Tertiary deposits consist of shale, sandstone and conglomerate (BGRMXUAR, 1993). The thick Xiyu conglomerate chiefly characterizes the Late Cenozoic deposits and the modern sedimentation (Charreau et al., 2005).

The northern piedmont of Tianshan was affected by intercontinental deformation (e.g. Tapponnier and Molnar, 1977; Avouac et al., 1993), which is documented by top to the north thrusts and folds (Fig. 2a). Although the principal structuration is recent (Tertiary to Quaternary), evidence of Mesozoic deformation is visible by sedimentation (Hendrix et al., 1992; Hendrix, 2000; Li et al., 2004), and a Mesozoic palaeorelief was inferred from the relationships between the basement and its sedimentary cover (Chen et al., 2011).

2.iii. West Junggar 
West Junggar is a mountainous massif located to the west of the Junggar Basin near the Kazakh-Chinese border (Fig 3a). The Early Palaeozoic basement is composed of volcanic arc rocks, turbidites and ophiolitic mélanges that recorded a pre-Upper Silurian deformation (Buckman and Aitchison, 2004; Choulet et al., 2012a). After a period of tectonic quiescence (Feng et al., 1989) and of alkaline magmatism (Chen et al., 2010), two new subduction zones developed, bounding the Early Palaeozoic basement. To the north, the Middle Devonian to Middle Carboniferous volcanic rocks, turbidites and ophiolitic mélanges are related to the south-directed (present coordinates) subduction of the Ob-Zaisan Ocean (Buslov et al., 2001). To the southeast, a magmatic arc is associated with a welldocumented accretionary complex composed of Carboniferous turbidites and ophiolitic mélanges (Zhang et al., 2011; Choulet et al., 2012b). A transition from the Carboniferous calk-alkaline magmatism toward the Permian alkaline magmatism attests to the termination of subduction process and is contemporaneous to the final collage of Central Asia (Chen \& Jahn, 2004). Lower Permian molasse is associated with alkaline lava flows (Buckman \& Aitchison, 2004), whereas Upper Permian pull-apart basins, with coarse clastic sedimentation developed along the Dalabute strike-slip fault (Allen \& Vincent, 1997).

In West Junggar, the post-Palaeozoic sedimentation is limited to the region near Karamay City that corresponds to the westernmost part of the Junggar Basin. The stratigraphic pile is very similar to that of North Tianshan. The Triassic layers are poorly exposed and often hidden by the transgressive Middle Jurassic strata (Lawrence, 1990). Nevertheless, some Triassic rocks are preserved in the intramountainous basin of Laba (Fig. 3b). Contrary to North Tianshan, the reactivation of the belt during Mesozoic and Cenozoic has been very limited in West Junggar. This difference is likely due to the orientation of pre-existing structures (e.g. the NE-SW striking Dalabute Fault) that hinders the development of major thrusts like in Tianshan. A prominent deformation is yet localized at the interface between the Palaeozoic basement and its sedimentary cover (Lawrence, 1990).

3. Palaeomagnetic sampling and methods 
Samples were collected on six sections from South and West Junggar, during three field trips held in 2008, 2009 and 2010. Figure 4 presents a synoptic chart of the Upper-Permian and Triassic formations of Northwest China with the stratigraphic position of the six investigated sections.

In South Junggar, the Urumqi section (Qijiagou section from Hendrix et al., 1992) is located about five kilometres to the east of Urumqi city (Fig. 2a). This section consists of a NE-SW trending asymmetric syncline with Upper Triassic strata in the middle and a periclinal termination to the northeast (Fig. 2b). The northwestern limb is slightly dipping, whereas the southeastern one is highly inclined and even occasionally overturned. The Lower Triassic rocks belong to the Shaofanggou Formation (Lower Cangfanggou Group) and consist of fine-grained red beds with lenticular sandstone encased in reddish to greenish shale and siltstone (Hendrix et al., 1992; Fig. 5a). The Karamay Formation of Middle Triassic age is a thick sequence of well-sorted imbricated conglomerate and sandstone, overlain by the braided-fluvial sandstone and siltstone of the Upper Triassic Huangshanjie Formation (Hendrix et al., 1992; Fig. 5b). The age assignment is based on palynostratigraphy, vertebrates (Metcalfe et al., 2009) and gasteropods, like Omphaloptycha, and plants, like Neocalamites (BGRMXUAR, 1993). The Lower and Upper Triassic strata from both limbs and the periclinal termination were sampled (Figs. $2 \mathrm{~b}$ and 4). 113 cores from 15 sites have been collected in this section (Table 1). It is worth to mention that the Lower and Upper Permian rocks from the same section were already collected for palaeomagnetic studies (Li et al., 1991; Sharps et al., 1992; Choulet et al., 2011; Fig. 2b).

The Tianchi section (South Junggar) is located about $50 \mathrm{~km}$ to the northeast of Urumqi (Figs. $2 \mathrm{a}$ and $2 \mathrm{~b}$ ). In this monoclinal section, there is no obvious unconformity between the basal midCarboniferous turbidites and the Late Carboniferous-Early Permian volcaniclastic sandstone (Carroll et al., 1990; Fig. 2b). The Permian sedimentary series fines down upward and grades into a thick pile of lacustrine mudstone, with intercalations of sandstone (Carroll et al., 1995; Fig. 5c). Coarse-grained clastic rocks of fluvial-alluvial origin characterize the top of the Permian (Carroll et al., 1990; 1995; Wartes et al., 2002), where the sandstone samples were collected (Lucaogou and Hongyanchi 
Formations; Figs. $2 \mathrm{~b}$ and 4). Rich faunas and floras constrain the age of the Permian series (see a review in Wartes et al., 2002). The sampling locality is close to that of Nie et al. (1993; Fig. 2b). Because this pole was different from the other Permian poles of this area (Li et al., 1991; Sharps et al., 1992; Choulet et al., 2011), we have conducted this new investigation in order to understand this discrepancy. 48 cores from 6 sites have been collected in this section (Table 1).

The Jimusar section (South Junggar) is located about $250 \mathrm{~km}$ to the east of Urumqi city, $10 \mathrm{~km}$ to the south of Jimusar city (Figs. 2a and 2c). The section consists of monoclinal alternations of mudstone, siltstone and sandstone (Fig. 5d) that were deposited in lacustrine and fluvial environments (Carroll, 1998; Wartes et al., 2002). Redbeds, which belong to the Upper Triassic Huangshanjie Formation, were collected in Jimusar (Figs. 2c and 4). Precise stratigraphic and time constraints are available for the Triassic and Permian series (Li et al., 1986; Yang et al., 1986; Ouyang \& Norris, 1999), since the Permian-Triassic boundary was investigated in detail along the Dalongkou section, 30 $\mathrm{km}$ to the east of the Jimusar section (Liu, 1994; Metcalfe et al., 2009). 51 cores from 6 sites have been collected in this section (Table 1).

The Aiwergou section is located to the west of the Turfan-Hami Basin and $100 \mathrm{~km}$ to the south of Urumqi City (Figs. 2a and 2d). This section displays a prominent unconformity of the Triassic monoclinal shallow dipping strata upon the gently folded Upper Permian (Greene et al., 2001; Wartes et al., 2002; Figs. 2d and 5e). At the basis of the section, well-sorted conglomerate with sandstone interlayers belongs to the Lower Triassic Jiucaiyuan Formation (Greene et al., 2001; Fig. 5f). The collected rocks consist of grey to pink sandstone, which constitutes the top of the formation (likely the Lower Triassic Shaofanggou Formation; Fig. 4). 58 cores from 8 sites have been collected in this section (Table 1).

The Laba section is located about $150 \mathrm{~km}$ to the west of Karamay City, in West Junggar (Figs. $3 \mathrm{a}$ and $3 \mathrm{~b}$ ). Triassic rocks belong to an intra-mountainous basin, bounded by two north-south trending brittle faults (Fig. 3b). These faults have controlled the opening of the basin; they correspond to reactivated Permian strike-slip faults that had juxtaposed Carboniferous turbidites with the Silurian 
ophiolitic mélange of Mayila (Choulet et al., 2012b; Fig. 5g). Triassic monoclinal and gently dipping strata are composed of conglomerate and sedimentary breccia to the base, and sandstone and siltstone to the top (Fig. 5h). Redbeds of Lower Tiassic Jianshangou Formation were collected (BRGMXUAR, 1993). However, no fossils are reported at Laba locality, and this assignment is based on lithological analogies with Lower Triassic Jianshangou Formation near Karamay City that contains Chasmatosaurus or Listrosaurus (BRGMXUAR, 1993). 42 cores from 8 sites have been collected in this section (Table 1).

Palaeomagnetic sampling was carried out using a portable gasoline-powered drill. The cores were oriented with magnetic and sun compasses, when possible, to correct for the local magnetic declinations. The average differences between magnetic and sun measurements are $2.3^{\circ}$ at Urumqi, $2.7^{\circ}$ at Tianchi, $1.6^{\circ}$ at Jimusar, and $4.4^{\circ}$ at Laba. A correction of $2.6^{\circ}$, corresponding to the International Geomagnetic Reference Field (IGRF) value for year 2010 has been applied to the samples from the Aiwergou section, where no sun measurements were available.

The magnetic mineralogy of this collection was investigated by several methods: 1) thermomagnetic measurements for determining the Curie points, 2) isothermal remanent magnetisation (IRM) acquisition and 3) hysteresis loops. The thermal magnetic experiments were carried out at Institut des Sciences de la Terre d'Orléans (ISTO) by using an AGICO KLY3S kappabridge susceptometer coupled to a CS3 furnace and a pump-assisted cooling system. Induced magnetisation was applied with an ASC Scientific IM-10-30 impulse magnetiser, and the IRM measurements were performed with an AGICO JR-5 automatic spinner magnetometer. Magnetic hysteresis curves were obtained with a homemade magnetic inductometer at Institut de Physique du Globe de Paris (IPGP). In addition, the anisotropy of the magnetic susceptibility (AMS) was measured by using an AGICO KLY3S kappabridge susceptometer, hosted at ISTO.

Stepwise thermal demagnetisations were performed to separate magnetic components. Four to nine specimens from each collected site were demagnetised with laboratory-built furnace, by ca. fifteen steps from room temperature up to $700^{\circ} \mathrm{C}$. Magnetic remanence was measured with an AGICO 
JR-5A automatic spinner magnetometer, hosted at ISTO. Inclinations and declinations obtained by stepwise demagnetisation were plotted on orthogonal vector diagrams (Zijderveld, 1967). Magnetic remanent directions were isolated using several methods: 1) the principal component analysis (Kirschvink, 1980), 2) the intersection of great circles (Hoffman \& Day, 1978), 3) the Fisher spherical statistics (Fisher, 1953), and 4) the combined analysis of great circles and stable points (McFadden \& McElhinny, 1988). Site-mean directions were computed with Fisher (1953) statistics. Palaeomagnetic software package of Cogné (2003) was used for data processing.

\section{Analytic Results}

\section{4.i. Magnetic mineralogy}

Representative results of thermomagnetic experiments are presented in Figure 6. All specimens, except those from Laba locality, display a sharp drop of the magnetic susceptibility between $500^{\circ} \mathrm{C}$ and $580^{\circ} \mathrm{C}$ (Figs. 6a to 6e), consistent with the Curie point of magnetite at $585^{\circ} \mathrm{C}$ (e.g. Dunlop \& Özdemir, 1997). A subsidiary decrease of the magnetic susceptibility from $600^{\circ} \mathrm{C}$ to $700^{\circ} \mathrm{C}$ is also observed and suggests a minor contribution of hematite. At Laba, a progressive drop of the magnetic susceptibility between $550^{\circ} \mathrm{C}$ and $700^{\circ} \mathrm{C}$ indicates that the magnetic mineralogy is dominated by hematite (Fig. 6f). The sharp drop of the susceptibility of some specimens from $300^{\circ} \mathrm{C}$ to $400^{\circ} \mathrm{C}$ may correspond to the transformation of maghemite, an iron oxide due to the oxidation of magnetite during weathering (Figs. 6a and 6b). Four out of six samples present a slight increase of the magnetic susceptibility over the range of $200-300^{\circ} \mathrm{C}$ (Figs. 6c, 6d and 6f). This may correspond to a mineral transformation of the original phase into a secondary magnetite. The irreversible trend of some thermomagnetic curves (e.g. Fig.6c, 6d and 6e) also suggests mineral transformation during heating and cooling processes. Except for specimens from Tianchi (Fig. 6c), the susceptibility is generally low, indicating a weak proportion of magnetic mineral within the studied rocks. 
In addition, IRM measurements were carried out on three out of the six sections to confirm the thermomagnetic measurements and they are presented in Figure 7. Samples from Tianchi display two magnetic behaviours (Fig. 7a): 1) a 90\% saturation before $300 \mathrm{mT}$, which might indicate a predominance of low-coercivity minerals, such as magnetite, and 2) an uncompleted saturation at 1200 $\mathrm{mT}$ that could reveal the coexistence of low and high-coercivity minerals, like magnetite and hematite, respectively. All specimens from Jimusar show a ca. 90\% saturation before $300 \mathrm{mT}$, indicating that magnetite is the principal magnetic remanent carrier (Fig. 7b). Like in Tianchi, samples from Aiwergou display two contrasting behaviours (Fig. 7c): 1) a total saturation before $200 \mathrm{mT}$ that is characteristic of magnetite, and 2) a rapid increase of magnetisation before $200 \mathrm{mT}$, followed by a weak slope and an uncompleted saturation until to $1200 \mathrm{mT}$. Such latter magnetic behaviour may confirm coexistence of low and high-coercivity minerals, like magnetite and hematite, respectively. (

Figure 8 displays the hysteresis loops of representative specimens from each section. A paramagnetic correction was applied to the linear part of original loops. For all specimens, the induced magnetic moment is of the order of $10^{1}$ to $10^{2} \mathrm{~mA} \cdot \mathrm{m}^{2} / \mathrm{kg}$, which, as noted above, indicates that the proportion of the magnetic minerals in the rock is relatively weak. For five out of six specimens, the loops are narrow-waisted (Figs. 8a to 8e) and this may suggest that low-coercivity minerals, like magnetite are predominant. The specimen from Laba (Fig. 8f) displays a broader loop, indicating that minerals of higher coercivity, like hematite, coexist with minor magnetite.

Thermomagnetic experiments, IRM measurements and hysteresis loops show that magnetite may be considered as the principal magnetic carrier in all the sections except Laba. Minor hematite is also inferred, especially in Tianchi and Aiwergou. Conversely, in Laba, high coercive mineral, like hematite seems to be the main magnetic carrier. Specimens collected in Urumqi have revealed maghemite indicating that rocks experienced post-deposition weathering.

4.ii. Anisotropy of the magnetic susceptibility

Although field observations of the gently folded or tilted strata (Fig. 5) do not support the existence of a pervasive deformation, we have checked for anisotropy of magnetic susceptibility on a 
representative set of specimens from three selected sections out of the six sampled ones (Urumqi, Jimusar and Aiwergou; Fig. 9). As expected, the magnetic anisotropy of this collection is characterised by a weak corrected anisotropy degree $\mathrm{P}_{\mathrm{J}}\left(\mathrm{P}_{\mathrm{J}}<1.04\right)$. The shape parameter $(\mathrm{T})$ indicates either oblate or prolate fabrics, without any regular trend. After bedding correction, the three principal magnetic anisotropy axes display a vertical well-grouped mean $\mathrm{K}_{3}$, pole of magnetic foliation, and shallow plunging and girdle-distributed $\mathrm{K}_{1}$, magnetic lineation (Fig. 7.C.9). This indicates that the original deposition surface was not significantly different from the horizontal and that these rocks have not experienced intensive deformation since deposition. At Jimusar, no preferred orientation of $\mathrm{K}_{1}$ axes can be inferred, but at Urumqi and Aiwergou, site-mean $\mathrm{K}_{1}$ axes are relatively clustered and average directions trend to NE-SW and NW-SE, respectively. At Urumqi, this direction is significantly different from N-S Middle and Upper Triassic palaeocurrents (Hendrix et al., 1992). At Aiwergou, no constraints on the Lower Triassic palaeocurrents are available. However, this NW-SE direction is compatible with a predicted direction interpolated from the Upper Permian easterly sediment transport (Greene et al., 2001) and from the Lower Jurassic south-directed palaeocurrents (Yu et al., 1996). A preferred orientation of minerals is also visible in the thin-sections of sandstone from Aiwergou.

\section{4.iii. Palaeomagnetic directions}

Progressive demagnetisation displays two magnetic components for most of the samples. A low temperature component (LTC) is isolated below $300-350^{\circ} \mathrm{C}$ from numerous specimens of all six sections. This component is northerly and steeply plunging downward before bedding correction (Fig. 10). In the Upper Triassic rocks collected near Urumqi, this LTC often persists up to high temperature $\left(550^{\circ} \mathrm{C}\right)$ and it is often the sole magnetic component recorded in the rocks. Except for the slightly abnormal directions of the LTC at Tianshi (Fig. 10c), five out of six sections display a well-grouped mean direction around the present-day geomagnetic field (PEF), computed after IGRF for year 2010, and the geocentric-dipole field (DF) directions (Fig. 10). Thus, LTC is most probably a recent and viscous magnetization. Although this component is not helpful for tectonic interpretations, the good 
clustering of LTC directions and the consistency between the site-mean directions and the PEF or DF directions attest to precise and coherent field-orientations during the sampling.

Samples from the Lower Triassic section of Urumqi display a high temperature component after removal of the LTC in the temperature range of $120^{\circ} \mathrm{C}-580^{\circ} \mathrm{C}$ (Fig. 11a). In geographic coordinates, the HTC are north to northeastward and steeply plunging downward, decaying to the origin. The comparison of the direction distribution before and after the bedding corrections reveals a significant dispersion of the site-mean directions in stratigraphic coordinates with respect to those in geographic coordinates (Figs. $11 \mathrm{~b}$ and 11c) and we calculated a locality-mean direction at: $\mathrm{D}_{\mathrm{g}}=15.3^{\circ}$, $\mathrm{I}_{\mathrm{g}}=58.7^{\circ}, \mathrm{k}_{\mathrm{g}}=34.2, \alpha_{95 \mathrm{~g}}=10.5^{\circ}$ and $\mathrm{Ds}=1.2^{\circ}, \mathrm{I}_{\mathrm{s}}=47.0^{\circ}, \mathrm{k}_{\mathrm{s}}=3.6, \alpha_{95 \mathrm{~s}}=37.0^{\circ}$, with $\mathrm{n}=7$ (Table 1).

Concerning the specimens from Upper Triassic of Urumqi, most samples show highly viscous low temperature component (Fig. 11d), and only 10 out of the 64 measured specimens display a stable high temperature component, with unblocking temperature above $300-350^{\circ} \mathrm{C}$ up to $580^{\circ} \mathrm{C}$. Among these 10 specimens, 3 of them show north to northwestward and steeply plunging downward directions (Fig. 11e), whereas others present unstable end-points at high temperature. Their directions were, therefore, estimated by great circle (Fig. 11f). A specimen-mean direction was calculated by the combined analysis of great circles and stable points (McFadden \& McElhinny, 1988) for this locality (Figs. $11 \mathrm{~g}$ and $11 \mathrm{~h}$ ): $\mathrm{D}_{\mathrm{g}}=325.4^{\circ}, \mathrm{I}_{\mathrm{g}}=33.4^{\circ}, \mathrm{k}_{\mathrm{g}}=21.2, \alpha_{95 \mathrm{~g}}=11.3^{\circ}$ and $\mathrm{D}_{\mathrm{s}}=325.8^{\circ}, \mathrm{I}_{\mathrm{s}}=49^{\circ}, \mathrm{k}_{\mathrm{s}}=$ $59.5, \alpha_{95 \mathrm{~s}}=6.7^{\circ}$, with $\mathrm{n}=10($ Table 1$)$.

After removing the LTC, specimens from the Upper Permian section of Tianchi display a high temperature component pointing toward the origin of the orthogonal plots (Fig. 12a and 12b) with an unblocking temperature over $300-350^{\circ} \mathrm{C}$. After bedding correction, this component is chiefly south to southwestward and steeply plunging upward (Fig. 12a). In addition, a north to northeastward and downward component is rarely observed (Fig. 12b). When plotted in stereoplot, site-mean directions are well grouped and we have calculated a locality-mean direction at: $\mathrm{D}_{\mathrm{g}}=283.3^{\circ}, \mathrm{I}_{\mathrm{g}}=-75.1^{\circ}, \mathrm{k}_{\mathrm{g}}=$ 137.2, $\alpha_{95 \mathrm{~g}}=5.7^{\circ}$ and $\mathrm{D}_{\mathrm{s}}=192.9^{\circ}, \mathrm{I}_{\mathrm{s}}=-60.0^{\circ}, \mathrm{k}_{\mathrm{s}}=52.4, \alpha_{95 \mathrm{~s}}=9.3^{\circ}$, with $\mathrm{n}=6$ (Figs. 12c and 12d; Table1). 
At Jimusar (Fig. 12e to 12h), after removal of the LTC and the random NRM, specimens collected in the Upper Triassic Huangshanjie Formation display a southerly and steeply upward high temperature component, in stratigraphic coordinates, decaying to the origin (Figs. 12e and 12f). Sitemean directions of this HTC cluster in stratigraphic and geographic coordinates (Figs. 12g and 12h). We have calculated a mean direction for this locality at: $\mathrm{D}_{\mathrm{g}}=212.2^{\circ}, \mathrm{I}_{\mathrm{g}}=-11.4^{\circ}, \mathrm{k}_{\mathrm{g}}=68.4, \alpha_{95 \mathrm{~g}}=8.2^{\circ}$ and $\mathrm{D}_{\mathrm{s}}=181.1^{\circ}, \mathrm{I}_{\mathrm{s}}=-64.4^{\circ}, \mathrm{k}_{\mathrm{s}}=44.1, \alpha_{95 \mathrm{~s}}=10.2^{\circ}$, with $\mathrm{n}=6($ Table 1$)$.

At Aiwergou (Fig. 13a to 13e), after removing the LTC, a high temperature component is also inferred. For half of the specimens, the principal component analysis was used to calculate this HTC, which is either southeastward and upward (Fig. 13a), or northwestward and downward (Fig. 13b). For other specimens, probably because of overlapping spectra of LTC and HTC unblocking temperatures, the great-circle method (Halls, 1978) was used to estimate the HTC direction (Fig. 13c). In some cases, the stable points and the great circles were combined to calculate the site-mean (Bailey \& Halls, 1984; McFadden \& McElhinny, 1988). Except an outlier that represents a coarse-grained facies, seven out of eight sites were used to calculate an average direction for the locality at (Figs. 13d and 13e): $\mathrm{D}_{\mathrm{g}}$ $=357.9^{\circ}, I_{g}=40.0^{\circ}, \mathrm{k}_{\mathrm{g}}=26.4, \alpha_{95 \mathrm{~g}}=12.0^{\circ}$ and $\mathrm{D}_{\mathrm{s}}=330.3^{\circ}, \mathrm{I}_{\mathrm{s}}=60.3^{\circ}, \mathrm{k}_{\mathrm{s}}=40.1, \alpha_{95 \mathrm{~s}}=9.6^{\circ}$, with $\mathrm{n}=$ 7 (Table 1).

After removing the LTC, the specimens from the Lower Triassic Jianshangou Formation at Laba (Fig. 13f to 13i) display a southeasterly and steeply upward high temperature component with unblocking temperatures at $300-350^{\circ} \mathrm{C}$ to the origin at $700^{\circ} \mathrm{C}$ (Figs. $13 \mathrm{f}$ and $13 \mathrm{~g}$ ). Although two isolated specimens display differences in inclinations (Table 1), site-mean directions are well grouped (Figs. 13h and 13i). We have calculated an average direction for this locality at: $D_{g}=195.2^{\circ}, I_{g}=-$ $71.8^{\circ}, \mathrm{k}_{\mathrm{g}}=46.8, \alpha_{95 \mathrm{~g}}=9.9^{\circ}$ and $\mathrm{D}_{\mathrm{s}}=151.0^{\circ}, \mathrm{I}_{\mathrm{s}}=-64.9^{\circ}, \mathrm{k}_{\mathrm{s}}=28.4, \alpha_{95 \mathrm{~s}}=12.8^{\circ}$, with $\mathrm{n}=6($ Table 1$)$. In addition, two sites (DQ07 and DQ08) corresponding to coarse grained facies like sedimentary breccia display random directions and were not taken into consideration for the average calculation (Table 1). 


\section{Discussion}

For these six sections, two magnetic components have been generally isolated from stepwise demagnetisation. The direction of the low temperature component (LTC) is consistent with the present-day geomagnetic field direction and is of viscous and recent origin. The high temperature components (HTC) with unblocking temperature over $300-350^{\circ} \mathrm{C}$ are carried by magnetite or, rarely hematite, like at Laba. Except few outliers due to a coarse-grained lithology, the HTC directions are well grouped and the locality-mean directions were calculated for each section. Before interpreting these directions in terms of tectonics, a discussion on the reliability and the age of the magnetisation is required, since Northwest China had experienced polyphase deformation.

5.i. Reliability of results and age of the magnetisation

The locality-mean directions of the HTC from Lower Triassic rocks of Urumqi display a unique normal polarity in geographic coordinates. The stereoplots also display a significant scattering of the site-mean directions after bedding correction, whereas the data are better clustered in geographic coordinates (Figs. 11b and 11c). The fold test is negative at $95 \%$, since the $\mathrm{kg}_{\mathrm{g}} / \mathrm{k}_{\mathrm{s}}$ ratio of 9.46 exceeds the F-distribution value $\mathrm{F}_{(12,12)}$ of 2.69 for the 5\% significance level (McElhinny, 1964); it means that the magnetisation was acquired after folding. To the northeast of Urumqi, the youngest tilted strata are of Late Jurassic age (BRGMXUAR, 1993), but to the southwest of Urumqi, Cretaceous and Tertiary strata form the core of syncline. Therefore, folding probably took place during the Tertiary period (Charreau et al., 2009) and this secondary magnetisation is probably syn to post-Tertiary. Furthermore, a tectonic origin for this remagnetisation seems unlikely, since folding of North Tianshan is relatively gentle and affects shallow crustal levels. No Cenozoic magmatic events are either recorded or inferred, ruling out the hypothesis of a thermal remagnetisation. Chemical processes might be, therefore, advanced. As North Tianshan experienced a polyphase reactivation (Hendrix et al., 1992) that culminated during the Tertiary, folding and thrusting have accommodated the exhumation of the Triassic strata (Dumitru et al., 2001; Charreau et al., 2009; Wang et al., 2009b). Therefore, the strata have been exposed to weathering, and alteration of the magnetic minerals was probably followed by 
recrystallization (Dunlop \& Özdemir, 1997). Occurrence of maghemite, which was inferred from our thermomagnetic experiments (Fig. 6a), argues for a secondary magnetisation, which may completely overprint the primary one. This remagnetisation is likely of Tertiary age, as the high temperature component is distinct from the LTC and the PEF directions. Therefore, we have calculated a Tertiary palaeomagnetic pole at: $\lambda=193.4^{\circ} \mathrm{N}, \Phi=77.8^{\circ} \mathrm{E}, \mathrm{A}_{95}=15.6^{\circ}, \mathrm{n}=7$ (see Section 5.ii for the remagnetisation age). Interestingly, the Triassic rocks of the Urumqi area experienced intense weathering, whereas no mineral alteration is documented in the adjacent Permian strata ( $\mathrm{Li}$ et al., 1991; Sharps et al., 1992; Choulet et al., 2011).

For the Upper Triassic rocks of Urumqi, a locality mean-direction of the high temperature component was calculated from specimens instead of sites, because only 10 out of 64 samples display HTC (Table 1). These HTC directions were isolated from both limbs of the syncline (Fig. 2b). The cluster of the directions is better in stratigraphic coordinates, and the precision parameter $\mathrm{k}$ is significantly improved after bedding corrections (Fig. 11b, Table 1). We applied the McFadden (1990) fold test. The statistical parameter $\xi_{1}\left(\xi_{2}\right)$ of 3.79 (4.54) in geographic coordinates is greater than the critical value $\left(\xi_{\mathrm{C}}\right)$ of $2.08(2.66)$ at the $95 \%(99 \%)$ confidence level, suggesting that the in situ mean direction is correlated with geographic coordinates. After bedding adjustment, the $\xi_{1}\left(\xi_{2}\right)$ value of 1.54 (2.04) is less than $\xi_{\mathrm{C}}$, so the tilt-corrected mean HTC direction is not correlated with bedding attitudes. The McFadden fold test is therefore positive at $95 \%$ and $99 \%$ and the HTC was acquired before the Tertiary folding. Although we could calculated a pre-Tertiary pole at: $\lambda=342.2^{\circ} \mathrm{N}, \Phi=59.6^{\circ} \mathrm{E}, \mathrm{A}_{95}=$ 5.8 , this pole was computed from only ten specimens. As a consequence, we exclude this locality from further discussion.

The stepwise demagnetisation curves of the Upper Permian rocks from Tianshi display two directions for the high temperature component: a principal south to southwestward and steeply plunging upward one and a minor north to northeastward and downward one (Figs. 12a and 12b). The sampled section is monoclinal, with moderately dipping strata. Although the precision parameter $\mathrm{k}$ decreases after bedding correction, the fold test (McElhinny, 1964) is inconclusive, since the value of 
$\mathrm{k}_{\mathrm{g}} / \mathrm{k}_{\mathrm{s}}(2.62)$ is lower than the $\mathrm{F}$-distribution value $\mathrm{F}_{(10,10)}$ of 2.98 for the $5 \%$ significance level (Figs. $12 \mathrm{c}$ and $12 \mathrm{~d}$, Table 1$)$. After bedding corrections, the two polarity means differ by $16.1^{\circ}$, which is less than the critical angle $\gamma_{c}$ of $23.4^{\circ}$, but the dataset is very unbalanced (one normal vs. five reverse directions) so that the reversal test is indeterminate (McFadden \& McElhinny, 1990). However, the occurrence of these two opposite polarities may suggest a primary magnetisation for these Late Permian sandstones. Therefore, we have calculated a new $\mathrm{P} 2$ pole at: $\lambda=80.0^{\circ} \mathrm{N}, \Phi=191.6^{\circ} \mathrm{E}, \mathrm{A}_{95}=$ $12.4^{\circ}, \mathrm{n}=6$ (Table 2).

The Late Triassic rocks from Jimusar were also collected along a monoclinal section. Though the precision parameter slightly decreases after bedding correction, the value of $\mathrm{k}_{\mathrm{g}} / \mathrm{k}_{\mathrm{s}}(1.55)$ is lower than the F-distribution value $\mathrm{F}_{(14,14)}$ of 2.48 for the $5 \%$ significance level. The fold test (McElhinny, 1964) is therefore not conclusive (Table 1). A unique polarity is observed and no reversal test could have been carried out. However, the occurrence of a single normal polarity cannot be a criterion to rule out the hypothesis of a primary magnetisation, since Late Triassic period is marked by successive long-lasting normal and reverse chrons (Gradstein et al., 2004). In this case, we propose to estimate the origin and the age of the magnetisation, by looking at the geological implications of the two possible palaeomagnetic poles (before and after bedding corrections). In Jimusar area, the Permian to Middle Jurassic strata experienced a folding episode that is postdated by the Pliocene deposits (Fig. 2c). In case of a secondary magnetisation, it would mean that the calculated pole before bedding corrections $\left(\lambda=42.6^{\circ} \mathrm{N}, \Phi=223.1^{\circ} \mathrm{E}\right)$ represents a period between the Late Jurassic and the present (the solely reverse polarity in geographic coordinate indicates that this remagnetisation is not due to PEF). Moreover, the comparison between this pole and the Late Jurassic-Early Cretaceous and Late Cretaceous-Early Tertiary poles of North Tianshan (Chen et al., 1991) shows a huge discrepancy in local inclination $\left(24.0^{\circ} \pm 5.0^{\circ}, 26.3^{\circ} \pm 6.1^{\circ}\right.$, respectively), requiring a latitudinal movement of at least $2500 \mathrm{~km}$ between these two localities. Evidence of such displacement is absent. To the opposite, the palaeomagnetic pole $\left(\lambda=87.5^{\circ} \mathrm{N}, \Phi=106.2^{\circ} \mathrm{E}, \mathrm{A}_{95}=13.1^{\circ}, \mathrm{n}=6\right)$ calculated after bedding corrections (Table 2) is more compatible $\left(-16.4^{\circ} \pm 11.2^{\circ},-14.1^{\circ} \pm 11.7^{\circ}\right)$ with the Mesozoic data of the 
Junggar Basin (Chen et al., 1991). Therefore, magnetisation more likely predates the tilting of the strata. As no thermal, tectonic and weathering events have occurred between sedimentation and folding, we assume that this magnetisation is likely primary and of Late Triassic age. Although this pole will be considered for tectonic implications, we are mindful that the lack of a reliable palaeomagnetic stability test may challenge further interpretations. Additional data would be required to assess our preliminary conclusions.

At Aiwergou, the Lower Triassic rocks display both normal and reverse polarities. After bedding corrections, the two polarity means differ by $15.1^{\circ}$, which is less than the critical angle $\gamma_{\mathrm{c}}$ of 21.6, but the precision parameters of each polarity mean are too much different to get a conclusive reversal test (McFadden \& McElhinny, 1990). Although data tend to cluster upon unfolding (Table 1), the value $\mathrm{k}_{\mathrm{s}} / \mathrm{k}_{\mathrm{g}}(1.52)$ is lower than the $\mathrm{F}$-distribution value $\mathrm{F}_{(14,14)}$ of 2.48 for the $5 \%$ significance level. The fold test (McElhinny, 1964) is therefore not conclusive. However, the occurrence of two polarities may suggest a primary magnetisation of detrital origin and of Early Triassic age. We propose a new palaeomagnetic pole for Early Triassic age at: $\lambda=68.0^{\circ} \mathrm{N}, \Phi=3.0^{\circ} \mathrm{E}, \mathrm{A}_{95}=14.6^{\circ}, \mathrm{n}=7$ (Table 2).

At Laba, the strata are shallow dipping (Table 1). Unfolding appears to slightly scatter the data. However, the value of $\mathrm{k}_{\mathrm{g}} / \mathrm{k}_{\mathrm{s}}(1.65)$ is lower than the $\mathrm{F}$-distribution value $\mathrm{F}_{(10,10)}$ of 2.97 for the $5 \%$ significance level. The fold test (McElhinny, 1964) is therefore not conclusive. Only the normal polarity has been isolated. As previously mentioned, West Junggar did not experience major tectonic or thermal event since Late Permian. Only a chemical origin can be envisaged for a possible remagnetisation, however samples do not show any evidence of intense alteration. The red colour of the red beds is due to pigmentary hematite that formed soon after sediment deposition. This hematite was discriminated by multiple methods of magnetic mineralogy determination. The growth Chemical Remanent Magnetisation (g-CRM) that hematite carries is related to diagenesis, and no recent weathering process did affect the high temperature component. Moreover, the pole calculated before bedding corrections $\left(\lambda=75.3^{\circ} \mathrm{N}, \Phi=117.6^{\circ} \mathrm{E}\right)$ would imply an absolute latitudinal motion of $27.4^{\circ} \pm 18.1^{\circ}$, i.e. $2500 \mathrm{~km}$ of West Junggar with respect to its Late Permian position $\left(\lambda=53^{\circ} \mathrm{N}, \Phi=\right.$ 
183.9 ${ }^{\circ}$ E from Choulet et al., 2011). In Central Asia, subductions have ceased before Permian and could not account for these huge Late Permian displacements. In addition, no significant (in palaeomagnetic terms) latitudinal motions between blocks surrounding West Junggar are observed during and after the Mesozoic (Chen et al., 1991; 1993; Gilder et al., 1996; 2008). Thus, we assume that $\mathrm{g}-\mathrm{CRM}$ of this formation represents a primary magnetisation. The palaeomagnetic pole calculated after bedding correction $\left(\lambda=69.9^{\circ} \mathrm{N}, \Phi=7.7^{\circ} \mathrm{E}, \mathrm{A}_{95}=20.6^{\circ}, \mathrm{n}=6\right)$ is more compatible in palaeolatitude with the West Junggar Upper Permian one's $\left(-17.5^{\circ} \pm 18.8^{\circ}\right.$, Choulet et al., 2011). Despite the lack of statistical test, this debatable pole will be used for tectonic interpretation assuming that the magnetisation is primary and of Early Triassic age.

\section{5.ii. Relative motions between blocks of Northwest China}

The pre-existing Late Permian pole of Tianchi in South Junggar, proposed by Nie et al. (1993) and re-calculated by Choulet et al. (2011), was significantly different from the mean South Junggar Permian pole (Choulet et al., 2011). Our new pole for the Late Permian rocks of Tianchi $\left(\lambda=80.0^{\circ} \mathrm{N}\right.$, $\Phi=191.6^{\circ} \mathrm{E}, \mathrm{A}_{95}=12.4^{\circ}$ ) is consistent with that of Nie et al. (1993), since angular difference is only of $4.6^{\circ} \pm 13.2^{\circ}$ (Fig. 14a). The angular difference between our Late Permian pole and the mean Permian one's from Choulet et al. (2011) is still significant $\left(23.0^{\circ} \pm 14.6^{\circ}\right)$. The origin of this angular difference is not well understood though that is related rather to clockwise $(\mathrm{CW})$ rotation $\left(31.1^{\circ} \pm 19.9^{\circ}\right)$ than latitudinal motion $\left(3.2^{\circ} \pm 9.5^{\circ}\right)$. It is likely that rotations around a vertical axis of the strata have caused this discrepancy. Although this value of rotation is relatively high, this situation may happen in case of syn-tectonic sedimentation processes. The occurrence of conglomerate intercalations in the Upper Lucaogou and Hongyanchi Formations, where cores were collected, supports the hypothesis of Late Permian local tectonics. As pointed out by Choulet et al. (2011), the mean South Junggar Permian pole displays a significant discrepancy in rotation with the Upper Permian poles of West Junggar, Tarim and Siberia. The calculated counterclockwise $(\mathrm{CCW})$ rotations of South Junggar with respect to the surrounding blocks are of the order of several tens of degrees $\left(-62.0^{\circ} \pm 23.7^{\circ},-52.2^{\circ} \pm 15.9^{\circ}\right.$ and - 
$73.9^{\circ} \pm 13.1^{\circ}$ relative to West Junggar, Tarim and Siberia, respectively), but latitudinal displacements remain weak and non-significant (Fig. 14a)

The Early Triassic palaeomagnetic poles of Laba (West Junggar) and Aiwergou (South Junggar) display an insignificant angular difference of $2.5^{\circ} \pm 23.4^{\circ}$ (Fig. 14b). The consistency between these poles refutes the idea that Cenozoic tectonics has partitioned the Junggar block into small blocks and that significant local rotations around vertical axis between these blocks have recently occurred (e.g. Gilder et al., 2008 for Tarim block). The observed movements between Junggar and the surrounding blocks cannot be regarded as an artefact of the Cenozoic tectonics, but the Mesozoic movements should be considered. However, a significant discrepancy exists between the Early Triassic poles from Tarim (McFadden et al., 1988; Zhu et al., 1998). Here, these declination differences are due to local vertical-axis block rotations that occurred over the last $20 \mathrm{Ma}$ (Gilder et al., 1996; 2008). On the basis of a large review of published palaeomagnetic data, Gilder et al., (2008) proposed a mean Late Carboniferous - Early Triassic pole, arguing a relative stable Tarim block. This pole was used for the calculations. The two compatible poles of West and South Junggar display significant $\mathrm{CCW}$ relative rotations of $-83.3^{\circ} \pm 15.8^{\circ}$ and $-63.3^{\circ} \pm 16.6^{\circ}$ with respect to Siberia and Tarim, respectively (Fig. 14b). However, the latitudinal movements between Junggar and Siberia $\left(3.4^{\circ} \pm 9.4^{\circ}\right)$ and between Junggar and Tarim $\left(-5.0^{\circ} \pm 10.0^{\circ}\right)$ are not significant (Fig. 4b).

Two new poles of possible Late Triassic age were computed for South Junggar at Urumqi and at Jimusar sections (Table 2), but we have not considered the pole from Urumqi for statistical reasons. The Late Triassic pole calculated at Jimusar section (Fig. 14c), will be here regarded as representative of the Junggar block, although we are aware that this assumption is still disputable. Additional data on Upper Triassic rocks from the Junggar block would help to improve these preliminary results, but others sections with analysable Upper Triassic rocks are presently not available. Besides, the Late Triassic pole of Tarim was calculated by interpolation of the linear trend between the C3-T1 and the J2 poles (Gilder et al., 2008; Table 2). We lend credence to this study as it is based on an extensive review of the literature and because geological processes experienced by Tarim were taken into 
consideration. Therefore, the Late Triassic pole of Tarim (Fang et al., 1990) that is away from the expected value was not included in the analysis (white dot in Fig. 14c). Figure 14c shows the Late Triassic poles indicating CCW rotations of Junggar relative to Siberia $\left(-51.6^{\circ} \pm 25.2^{\circ}\right)$ and Tarim ($\left.23.4^{\circ} \pm 20.9^{\circ}\right)$. Again, no significant N-S movement between Junggar and Siberia $\left(10.9^{\circ} \pm 12.7^{\circ}\right)$ or between Junggar and Tarim $\left(-8.8^{\circ} \pm 11.9^{\circ}\right)$ can be advanced.

The likely Cenozoic pole obtained from Lower Triassic remagnetised rocks of Urumqi is consistent with the Lower Cenozoic palaeopole of Junggar (Chen et al., 1991), since an angular difference of $7.9^{\circ} \pm 11.8^{\circ}$ is observed (Fig. 14d). In addition, Chen et al. (1991) have proposed that during Late Mesozoic and Cenozoic times Junggar was relatively stable relative to its present-day position. The $\mathrm{J}_{3}-\mathrm{Cz}$ pole of Junggar is compatible with that of Tarim (angular difference equal to $7.7^{\circ} \pm$ $8.4^{\circ}$ ) and with the apparent polar wander path (APWP) of Eurasia (Besse \& Courtillot, 1991) since the Early Cretaceous. Actually, the angular difference of the Cenozoic pole of Urumqi with the AWPW pole at $40 \mathrm{Ma}$ is only $9.2^{\circ} \pm 12.1^{\circ}$ (Fig. 14d).

5.iii. The Early Triassic single rigid Junggar block

The consistency of the Early Triassic poles of Laba (West Junggar) and Aiwergou (South Junggar) suggests that no more displacement between these two blocks occurred since that time. Therefore, Junggar can be regarded as a rigid block since the Early Triassic. In fact, a rigid Junggar block during the Palaeozoic was suggested in many previous palaeomagnetic studies (Li et al., 1991; Wang et al., 2007). However, the palaeomagnetic directions of the Late Carboniferous to Permian rocks from West and South Junggar display significant differences in inclination and declination (Choulet et al., 2011; Fig. 14a). These results challenge the idea of a rigid Junggar block in Late Palaeozoic. Choulet et al. (2011) rather suggest that West and South Junggar underwent individual evolution related to the inheritance of the Palaeozoic geodynamics.

West Junggar is partly composed by an accretionary complex, including ophiolitic mélanges bounded to the north by a magmatic arc (Geng et al., 2011). Structural constraints suggest 
northwestward direction (present coordinates) of the Late Palaeozoic subduction (Choulet et al., 2012b). North Tian Shan also presents a southern magmatic arc bounded by a northern accretionary complex with ophiolitic mélanges and structural data constrain a south-directed Late Palaeozoic subduction (Wang et al., 2006). Westward extensions of these units form a horseshoe-shaped structure, which has been long recognized as the Kazakhstan orocline (Zonenshain et al., 1990; Abrajevitch et al., 2008). Therefore, West Junggar and North Tianshan (South Junggar) were parts of the same active margin that enclosed the Junggar Ocean (Choulet et al., 2012b; Fig. 15). According to the palaeogeographic reconstructions, the increase of the orocline curvature is accommodated by the reduction of the inner oceanic domain, caused by Devonian to Carboniferous subduction of the Junggar Ocean below Tian Shan, Kazakhstan and West Junggar margins (Wang et al., 2006; Windley et al., 2007; Choulet et al., 2012b). During the Permian, the oceanic domains have been completely removed (Windley et al., 2007), and now the oceanic remnants are solely found within the ophiolitic mélanges surrounding the Alakol and Junggar Quaternary sedimentary basins. Therefore, the suture zone of Junggar Ocean is cryptic (Fig. 15), but may be tracked by geophysical surveying, since transcrustal and translithospheric discontinuities and low to mid-crustal high conductivity bodies have been revealed below the Junggar Bassin (Zhao et al., 2003).

Nevertheless, oroclinal bending can only account for the half of the present belt curvature (Abrajevitch et al, 2008). Another half is due to the Permian "orocline disarticulation" assisted by the block rotations around vertical axes (Levashova et al., 2003; Van der Voo, 2006; Wang et al., 2007). Movements along strike-slip faults in the whole Altaids (Laurent-Charvet et al., 2002; 2003; Natal'in and Sengör, 2005) have accommodated these rotations and the related displacements were estimated to several hundred of kilometres in Tianshan and Altai (Wang et al., 2007; Choulet et al., 2011; Fig. 15). The Ar-Ar geochronological investigations, carried out on mylonites from Tianshan and Altai, indicate transcurrent movements between the Late Carboniferous and the Early Triassic (Laurent-Charvet et al., 2003). These faults likely stem from the individual rotations of West and South Junggar with respect to their surrounding blocks (Choulet et al., 2011). In addition, structures related to transpressive deformation in the West Junggar accretionary prism (Choulet et al., 2012b) and ridge 
subduction (Geng et al., 2009; Tang et al., 2010) document a non-frontal Carboniferous subduction of the Junggar Ocean. This oblique subduction has evolved to a Permian oblique collage (Choulet et al., 2012b). Therefore, the hidden suture of the palaeo-Junggar Ocean, representing the limit between West and South Junggar, may have been reactivated as a strike-slip fault during the Permian (Fig. 15). Like in numerous regions of Central Asia, the transcurrent motions have persisted until the Early Triassic (Melnikov et al., 1998; Laurent-Charvet et al., 2003). In consequence, no more relative displacement are recorded between West and South Junggar after the Early Triassic, and then Junggar may have evolved as a single rigid block.

\section{5.iv. Mesozoic tectonics in Northwest China}

Though the previous studies have emphasized the Late Palaeozoic deformation (Wang et al., 2007; Choulet et al., 2011), the comparison of the palaeomagnetic poles from Junggar, Tarim and Siberia ranging from the Late Permian to the Cenozoic show the importance of the Mesozoic relative movements between these blocks, which are essentially rotations. Since Junggar became a rigid block at Early Triassic and relatively compatible Cenozoic poles are observed among Junggar, Tarim and Siberia, the observed rotations are neither local nor related to a late Cenozoic deformation. These rotations rather correspond to the large-scale Mesozoic tectonic episodes, which need to be discussed in detail.

The comparison of the Late Permian poles of South Junggar, West Junggar, Tarim and Yili (Fig. 14a) infers that important rotations may have occurred after the Late Permian (Choulet et al., 2011), but no upper limit of these motions was available yet. These rotations were supposed to be accommodated by strike-slip faults in Altai and Tianshan (Wang et al., 2007; Choulet et al., 2011). Actually, mylonites have recorded a ductile transcurrent deformation up to the Early Triassic along the Irtysch-Gornotsaev shear zone or the Chingiz-Alakol-North Tianshan Fault (Melnikov et al., 1998; Laurent-Charvet et al., 2003). The CW rotations of South Junggar relative to Tarim and Siberia from the Late Permian to the Early Triassic are estimated to $11.1^{\circ} \pm 17.9^{\circ}$ and $9.4^{\circ} \pm 18^{\circ}$, respectively (Table 3). Despite non-significant values, the inferred rotation of South Junggar with respect to these two 
adjacent blocks is clockwise, instead of the anticlockwise movement deduced from Late Permian poles. This unexpected kinematics may results from discrete (in space and time) transcurrent movements in Altai and Tianshan, but their tectonic origin is still an open question. It is widely accepted that the Irtysch-Gornotsaev Shear Zone (Fig. 1b) is a Late Palaeozoic sinistral shear zone (Laurent-Charvet et al., 2002; Buslov et al., 2004; Natal'in and Sengör, 2005), but dextral kinematic is also recorded between $244 \pm 3 \mathrm{Ma}$ and $249 \pm 2 \mathrm{Ma}$ (Laurent-Charvet et al., 2003). According to the curved shape of the Irtysch zone, this Early Triassic dextral shearing may have accommodates a CW rotation of South Junggar with respect to Tarim. In Tianshan, dextral Late Permian to Early Triassic movements along the Nalati and the Main Tianshan faults (Fig. 1b) are also described (LaurentCharvet et al., 2003; de Jong et al., 2009). Late Permian - Early Triassic shearing along the North Tianshan Fault is little documented (de Jong et al., 2009) and the post-Permian rotation between Yili and South Junggar is null (Wang et al., 2007) or weak (Choulet et al., 2011). The true Late-PermianEarly Triassic boundary between Junggar and Tarim may be therefore represented by the Nalati and Main Tianshan faults that display a curved shape. If the Euler pole related to a rotation along these faults is located in Tarim, dextral motions along these faults may have accommodated the Late Permian-Early Triassic CW rotation of Junggar block relative to Tarim. Although the Early Triassic poles of Laba and Aiwergou suggest a rigid Junggar block, this Junggar block seems to have experienced important post-Early Triassic CCW rotations with respect to Siberia and Tarim (Table 3). This suggests that displacements ascribed to the pre-Early Triassic transcurrent tectonics were probably overemphasized by the previous studies (Wang et al., 2007; Choulet et al., 2011) and that a great part of the relative displacements between Tarim, Junggar and Siberia was rather accommodated since the Early Mesozoic (Fig. 16).

The post-Early Triassic CCW rotations $\left(-63.3^{\circ} \pm 16.6^{\circ}\right)$ between Junggar and Tarim were partly accommodated by the Middle Triassic reactivation of the Palaeozoic faults in the Tianshan (Fig. 16), since the rotation of Junggar relative to Tarim between the Early and the Late Triassic was estimated at $-39.9^{\circ} \pm 20.8^{\circ}$ (Table 3). Evidence of such a deformation may be recorded by the $300 \mathrm{~m}$ thick conglomerate of the Karamay Formation, observed in Junggar, Tarim and Turfan-Hami basins 
(Hendrix et al., 1992; Greene et al., 2001) and the contemporaneous unconformity. At the present time, the Middle to Late Triassic movements between Siberia and Junggar are not documented by geologic evidence in Altai, but brittle faulting in the Irtysch zone remains poorly constrained. The origin of the mid-Triassic reactivation could be related to the Triassic collision of the Qiangtang block with the basement of the Songpang-Ganzi terrane (Yin \& Harrison, 2000). Based on the diachronous arc magmatism from west to east (Searle, 1991; Burchfiel et al., 1995), the collision was likely oblique (Yin \& Harrison, 2000) and this may have favoured transpressive reactivation tectonics in Tianshan. The Late Triassic poles display significant CCW rotation movements of Junggar relative to Siberia ($51.6^{\circ} \pm 25.2^{\circ}$ ) and Tarim $\left(-23.4^{\circ} \pm 20.9^{\circ}\right)$ (Table 3). Consequently, the Triassic tectonics can only account for a part of the post-Early Triassic rotations and younger tectonics must be forwarded.

As pointed out by the previous studies, rotations of less than ten degrees were calculated between the mean Mesozoic poles of South Junggar (by averaging J3-K1 and K2-Cz1 poles) and those of Tarim and Siberia (Chen et al., 1991, 1993). Therefore, only a small part of the large-scale rotations inferred from the Triassic palaeomagnetic data is due to the post-Jurassic tectonics. In other words, it means that the CCW rotation of Junggar with respect to Tarim between the Late Triassic and the Late Jurassic-Early Cretaceous periods was accommodated by displacements along Jurassic strike-slip faults, although the value of $-15.8^{\circ} \pm 17.9^{\circ}$ may be regarded as not significant (Table 3 ). The Jurassic tectonics is not well documented in Tianshan, but geological evidence can be found in the sedimentary pile. The thick conglomerate sequences of the Badaowan Formation (J1) and the Kalaze Formation (J3-K1) may indicate an intense basin subsidence controlled by tectonic processes (Hendrix et al., 1992; Hendrix, 2000). This tectonic was accompanied by the formation of an Early Mesozoic relief in Tianshan (Hendrix et al., 1992; Sobel \& Dimitru, 1997; Dimitru et al., 2001; Greene et al., 2001; Jolivet et al., 2010; Chen et al., 2011). An angular unconformity is also visible at the top of the Jurassic layers (Chen et al., 2011). Similarly to the Middle Triassic intracontinental deformation, the Late Jurassic deformation is usually described as a far-field effect of the collision between the Lhasa block and the Asian margin (Hendrix et al., 1992). Like for the Qiangtang block, the collision is diachronous along strike (Dewey et al., 1988; Gaetani et al., 1993) and Late Jurassic transpressive 
reactivation is usually advanced in Tarim or Tianshan regions (McKnight et al., 1990; Nishidai and Berry, 1990; Hendrix et al., 1992). The Early Jurassic reactivation along Tianshan is not well documented and its origin is unclear. It could be due to a far-field effect of the late collisional movements in the Songpang-Ganzi area (Yin \& Harrison, 2000).

The Mesozoic intracontinental deformation is also described in Altai and Mongolia (de Grave et al., 2007; Jolivet et al., 2007) and could account for the post-Late Triassic CCW relative rotation of Junggar with respect to Siberia $\left(-51.6^{\circ} \pm 25.2^{\circ}\right)$ (Table 3). However, the position of Siberia remains problematic. Siberia and Europe formed Eurasia after the Permian collision in the Urals and, usually, the synthetic Eurasian APWP (Besse \& Courtillot, 1991; 2002) is used to represent Siberia. However, the important inclination discrepancies between the Central Asian blocks and Siberia led many authors to consider that Eurasia might not be a rigid plate (Cogné et al., 1999; Hankard et al., 2007; Gilder et al., 2008; Cogné et al., 2013) and that movements of Siberia relative to Europe may have occurred during the Mesozoic and/or the Cenozoic. Therefore, it is rather difficult to give credence to the inferred Triassic and Jurassic rotations of Junggar with respect to Siberia at the present time.

\section{Conclusion}

Constraining the past tectonic events is a crucial issue to understand the present geometry of Central Asia. The geological and the geophysical studies have focused on the Late Palaeozoic transcurrent episode and the Tertiary reactivation. However, much uncertainty has remained about the Mesozoic, which was generally considered as a period of tectonic quiescence. Sedimentary data, combined with recent structural and geochronological results have suggested possible Mesozoic reactivations, but no kinematic constraints were currently available.

This study presents new palaeomagnetic results from Permian and Triassic sedimentary rocks collected around the Junggar basin. Newly obtained poles suggest that Junggar might be regarded as a rigid block only after Early Triassic. Comparison of palaeomagnetic poles from Junggar and Tarim blocks reveals significant post-Permian relative rotations due to the probable reactivation of Permian 
strike-slip faults under brittle conditions, though more field surveys are needed for geological evidence.

These new results are in agreement with the hypothesis of a Mesozoic intracontinental reactivation in Central Asia in response to a far-field effect of the Tibetan collisions. Although the current physiography of Central Asia is due to the recent tectonics, the Mesozoic episode has probably played an important role on the present geometric pattern. However, these interpretations and conclusions are still preliminary, other palaeomagnetic constraints are necessary to improve the kinematic scenario advanced in this study.

\section{Acknowledgments}

This study was supported by National Basic Research Program of China (973 Project Nos. 2009CB825008, 2007CB411301), Chinese National S\&T Major Project (2008ZX05008), and the project "Paleomagnitic study on the tectonic and paleogeographic evolution of northwest of China" funded by SINOPEC, and co-sponsored by National Nature Science Foundation of China (40821002, 40802043). We are grateful to $M$. Santosh, and two anonymous reviewers for their valuable comments, which have helped to significantly improve the paper. 


\section{References}

Abrajevitch, A., van der Voo, R., Bazhenov, M.L., Levashova, N.M., McCausland, P.J.A., 2008. The role of the Kazakhstan orocline in the late Palaeozoic amalgamation of Eurasia. Tectonophysics $455,61-76$.

Abrajevitch, A.V., van der Voo, R., Levashova, N.M., Bazhenov, M.L., 2007. Paleomagnetism of the mid-Devonian Kurgasholak Formation, Southern Kazakhstan: Constraints on the Devonian paleogeography and oroclinal bending of the Kazakhstan volcanic arc. Tectonophysics 441, 67-84.

Allen, M.B., Vincent, S.J., 1997. Fault reactivation in the Junggar region, northwest China: the role of basement structures during Mesozoic-Cenozoic compression. Journal of the Geological Society $154,151-155$.

Avouac, J.-P., Tapponnier, P., Bai, M., You, H., Wang, G., 1993. Active thrusting and folding along the northern Tien-Shan and Late Cenozoic rotation of the Tarim relative to Dzungaria and Kazakhstan. Journal of Geophysical Research 98, 6755-6804.

Badarch, G., Cunningham, W.D., Windley, B.F., 2002. A new terrane subdivision for Mongolia: implications for the Phanerozoic crustal growth of Central Asia. Journal of Asian Earth Sciences $21,87-110$.

Bailey, R.C., Halls, H.C., 1984. Estimate of confidence in paleomagnetic directions derived from remagnetization circle and direct observational data. Journal of Geophysics 54, 174-182.

Besse, J., Courtillot, V., 1991. Revised and synthetic apparent polar wander paths of the African, Eurasian, North American and Indian plates, and true polar wander since $200 \mathrm{Ma}$, Journal of Geophysical Research 96, 4029-4050.

Besse, J., Courtillot, V., 2002. Apparent and true polar wander and the geometry of the geomagnetic field in the last 200 million years. Journal of Geophysical Research 107 (B11), 2300, doi:10.129/2000JB000050.

BGMRXUAR (Bureau of Geology and Mineral Ressources of Xinjiang Uygur Autonomous Region), 1993. Regional Geology of Xinjiang Uygur Autonomous Region Geological Publishing House, Beijing. 841 pp. (in Chinese). 
Buckman, S., Aitchison, J.C., 2004. Tectonic evolution of Paleozoic terranes in West Junggar, Xinjiang, NW China, In: Malpas, J., Fletcher, C.J., Aitchison, J.C. (Eds.), Aspects of the Tectonic Evolution of China. The Geological Society, London, Special Publication 226, pp. 101-129.

Burchfiel, B.C., Chen, Z., Liu, Y., Royden, L.H., 1995. Tectonics of the Longmen Shan and adjacent regions, central China. International Geology Review 37, 661-735.

Buslov, M.M., Saphonova, I.Y., Watanabe, T., Obut, O.T., Fujiwara, Y., Iwata, K., Semakov, N.N., Sugai, Y., Smirnova, L.V., Kazansky, A.Y., 2001. Evolution of the Paleo-Asian Ocean (AltaiSayan Region, Central Asia) and collision of possible Gondwana-derived terranes with the southern marginal part of the Siberian continent. Geosciences Journal 5, 203-224.

Buslov, M.M., Watanabe, T., Fujiwara, Y., Iwata, K., Smirnova, L.V., Safonova, I.Y., Semakov, N.N, Kiryanova, A.P., 2004. Late Paleozoic faults of the Altai region, Central Asia: tectonic pattern and model of formation. Journal of Asian Earth Sciences 23, 655-671.

Carroll, A.R., 1998. Upper Permian lacustrine organic facies evolution, Southern Junggar, NW China. Organic Geochemistry 28, 649-667.

Carroll, A.R., Graham, S.A., Hendrix, M.S., Ying, D., Zhou, D., 1995. Late Paleozoic tectonic amalgamation of NW China: sedimentary records of the northern Tarim, northwestern Turpan, and southern Junggar basins. Geological Society of America Bulletin 107, 571-594.

Carroll, A.R., Graham, S.A., Hendrix, M.S., Ying, D., Zhou, D., 1995. Late Paleozoic tectonic amalgamation of NW China: sedimentary records of the northern Tarim, northwestern Turpan, and southern Junggar basins. Geological Society of America Bulletin 107, 571-594.

Carroll, A.R., Liang, Y.H., Graham, S.A., Xiao, X.C., Hendrix, M.S., Chu, J.C., mcknight, C.L., 1990. Junggar Basin, Northwest China - trapped Late Paleozoic ocean. Tectonophysics 181, 1-14.

Charreau, J., Chen, Y., Gilder, S., Dominguez, S., Avouac, J.-P., Sen, S., Sun, D.J., Li, Y.G., Wang, W.M., 2005. Magnetostratigraphy and rock magnetism of the Neogene Kuitun He section (northwest China): implications for Late Cenozoic uplift of the Tianshan mountains. Earth and Planetary Science Letters 230, 177-192. 
Charreau, J., Gumiaux, C., Avouac, J.-P., Augier, R., Chen, Y., Barrier, L., Gilder, S., Dominguez, S., Charles, N., Wang, Q.C., 2009. The Neogene Xiyu Formation, a diachronous prograding gravel wedge at front of the Tianshan : Climatic and tectonic implications. Earth and Planetary Science Letters 287, 298-310.

Charvet, J., Shu, L.S., Laurent-Charvet, S., 2007. Paleozoic structural and geodynamic evolution of eastern Tianshan (NW China): welding of the Tarim and Junggar plates. Episodes 30, 162-186.

Charvet, J., Shu, L.S., Laurent-Charvet, S., Wang, B., Faure, M., Cluzel, D., Chen, Y., de Jong, K., 2011. Palaeozoic tectonic evolution of the Tianshan belt, NW China. Science in China Earth Science 54, 166-184, doi: 10.1007/s11430-010-4138-1.

Chen, B., Jahn, B.M., 2004. Genesis of post-collisional granitoids and basement nature of the Junggar Terrane, NW China: Nd-Sr isotope and trace element evidence. Journal of Asian Earth Sciences 23, 691-703.

Chen, J.F., Han, B.F, Ji, J.Q., Zhang, L., Xu, Z., He, G.Q., Wang, T., 2010. Zircon U-Pb ages and tectonic implications of Paleozoic plutons in northern West Junggar, North Xinjiang, China. Lithos $115,137-152$.

Chen, K., Gumiaux, C., Augier, R., Chen, Y., Wang, Q.C., Lin, W., Wang, S.L., 2011. The Mesozoic palaeorelief of the northern Tian Shan (China). Terra Nova 23, 195-205.

Chen, Y., Cogné, J.-P., Courtillot, V., Avouac, J.-P., Tapponnier, P., Buffetaut, E., Wang, G.Q, Bai, M.X., You, H.Z., Li, M., Wei, C.S., 1991. Paleomagnetic study of Mesozoic continental sediments along the Northern Tien Shan (China) and heterogeneous strain in central Asia. Journal of Geophysical Research 96, 4065-4082.

Chen, Y., Courtillot, V., Cogne, J.-P., Besse, J., Yang, Z. Y., Enkin, R., 1993. The configuration of Asia prior to the collision of India: Cretaceous paleomagnetic constraints. Journal of Geophysical Research 98, 21927-21941.

Choulet, F., Cluzel, D., Faure, M., Lin, W., Wang, B., Chen, Y., Wu, F.Y., Ji, W.B., 2012a. New constraints on the pre-Permian continental crust growth of Central Asia (West Junggar, China) by 
$\mathrm{U}-\mathrm{Pb}$ and $\mathrm{Hf}$ isotopic data from detrital zircon. Terra Nova, in press, doi:10.1111/j.13653121.2011.01052.x.

Choulet, F., Chen, Y., Wang, B., Faure, M., Cluzel, D., Charvet, J., Lin, W., Xu, B., 2011. Late Palaeozoic palegeographic reconstruction of western Central Asia based upon paleomagnetic data and its geodynamic implications. Journal of Asian Earth Sciences 42, 867-884.

Choulet, F., Faure, M., Cluzel, D., Chen, Y., Lin, W., Wang, B., 2012b. From oblique accretion to transpression in the evolution of the Altaid collage: New insights from West Junggar, northwestern China. Gondwana Research 21, 530-547.

Coe, R.S., Globerman, B.R., Plumley, P.W., Thrupp, G.A., 1985. Paleomagnetic results from Alaska and their tectonic implications, In: Howell, D.G. (Ed.), Tectonostratigraphic terranes of the CircumPacific region. Amer. Assoc. Petrol. Geol., Circum-Pacific Council for Energy and Mineral Resources Series 1, pp. 85-108.

Cogné, J.-P., 2003. A Macintosh TM application for treating paleomagnetic data and making plate reconstructions. Geochemical Geophysical Geosystems 4, doi:10.1029/2001GC000227.

Cogné, J.-P., Halim, N., Chen, Y., Courtillot, V., 1999. Resolving the problem of shallow magnetizations of Tertiary age in Asia: Insights from paleomagnetic data from the Qiangtang, Kunlun, and Qaidam blocks (Tibet, China), and a new hypothesis. Journal of Geophysical Research $104,17,715-17,734$.

Cogné, J.-P., Besse, J., Chen, Y., Hankard, F., 2013. A new Late Cretaceous to Present APWP for Asia and its implications for paleomagnetic shallow inclinations in Central Asia and Cenozoic Eurasian plate deformation. Geophysics Journal International, doi:10.1093/gji/ggs104.

De Grave, J., Buslov, M.M., van den Haute, P., 2007. Distant effects of India-Eurasia convergence and Mesozoic intracontinental deformation in Central Asia: Constraints from apatite fission-track thermochronology. Journal of Asian Earth Sciences 29, 188-204.

De Jong, K., Wang, B., Faure, M., Shu, L., Cluzel, D., Charvet, J., Ruffet, G., Chen, Y., 2009. New ${ }^{40} \mathrm{Ar} /{ }^{39} \mathrm{Ar}$ age constraints on the Late Paleozoic tectonic evolution of the western Tianshan 
(Xinjiang, northwestern China), with emphasis on Permian fluid ingress. International Journal of Earth Sciences 98, 1239-1258.

Degtyarev, K.E., 2011. Tectonic evolution of Early Paleozoic Island-arc systems and continental crust formation in the Caledonides of Kazakhstan and the North Tien Shan. Geotectonics 45, 23-50.

Demarest, T.J., 1983. Error analysis for the determination of the tectonic rotation from paleomagnetic data. Journal of Geophysical Research 88, 4321-4328

Dewey, J.F., 1988. The tectonic evolution of the Tibetan Plateau. Philosophical Transaction of the Royal Society London serie A 327, 379-413.

Dumitru, T. A., Zhou, D., Chang, E., Graham, S. A., Hendrix, M. S., Sobel, E. R., Carroll, A. R., 2001. Uplift, exhumation, and deformation in the Chinese Tian Shan, In: Hendrix, M.S., Davis, G.A. (Eds.), Paleozoic and Mesozoic tectonic evolution of central and eastern Asia: From continental assembly to intracontinental deformation. Geological Society of America Memoir 194, pp. 71-99.

Dunlop, D.J., Ozdemir, O., 1997. Rock magnetism, Fundamentals and Frontiers. Cambridge University Press, Cambridge, 573 pp..

Enkin, R.J., Yang, Z., Chen, Y., Courtillot, V., 1992. Paleomagnetic constraints on the geodynamic history of the major blocks of China from the Permian to the Present. Journal of Geophysical Research 97, 13953-13989.

Fang, D., Chen, H., Jin, G., Guo, Y., Wang, Z., Tan, X., Yin, S., 1990. Late Paleozoic and Mesozoic paleomagnetism and tectonic evolution of Tarim terrane, In: Wiley, T.J., Howell, D.G., Wong, F.L. (Eds.), Terrane analysis of China and the Pacific rim, Circum-Pacific Council for Energy and Mineral Resources. Earth Science Series 13, pp. 251-255.

Feng, Y., Coleman, R.G., Tilton, G., Xiao, X., 1989. Tectonic evolution of the West Junggar region, Xinjiang, China. Tectonics 8, 729-752.

Filippova, I.B., Bush, V.A., Didenko, A.N., 2001. Middle Paleozoic subduction belts: the leading factor in the formation of the Central Asian fold-and-thrust belt. Russian Journal of Earth Sciences $3,405-426$.

Fisher, R., 1953. Dispersion on a sphere. Proceedings of the Royal Society, series A 217, 295-305. 
Gaetani, M., Jadoul, F., Erba, E., Garzanti, E., 1993. Jurassic and Cretaceous orogenic events in the North Karakorum: age constraints from sedimentary rocks, In: Treloar, P.J., Searle, M.P. (Eds.), Himalayan Tectonics. The Geological Society, Special Publication 74, 39-52.

Gao, J., Li, M.S., Xiao, X.C., Tang, Y.Q., He, G.Q., 1998. Paleozoic tectonic evolution of the Tianshan orogen, northwestern China. Tectonophysics 287, 213-231.

Geng, H.Y., Sun, M., Yuan, C., Xiao, W.J., Xian, W.S., Zhao, G.C., Zhang, L.F., Wong, K., Wu, F.Y., 2009. Geochemical, Sr-Nd and zircon U-Pb-Hf isotopic studies of Late Carboniferous magmatism in the West Junggar, Xinjiang: Implications for ridge subduction? Chemical Geology 266, 373-398.

Geng, H.Y., Sun, M., Yuan, C., Zhao, G.C., Xiao, W.J., 2011. Geochemical and geochronological study of early Carboniferous volcanic rocks from the West Junggar: Petrogenesis and tectonic implications. Journal of Asian Earth Sciences 42, 854-866.

Gilder, S.A., Gomez, J., Chen, Y., Cogné, J.-P., 2008. A new paleogeographic configuration of the Eurasian landmass resolves a paleomagnetic paradox of the Tarim Basin (China). Tectonics, 27, TC1012, doi: 10.1029/2007TC002155.

Gilder, S.A., Zhao, X.X., Coe, R.S., Meng, Z.F., Courtillot, V., Besse, J., 1996. Paleomagnetism, tectonics and geology of the southern Tarim Basin, northwestern China. Journal of Geophysical Research 101, 22,015-22,031.

Gradstein, F.M., Ogg, S.G., Smith, A.G., 2004. A Geologic Time Scale. Cambridge University Press, Cambridge, 589 pp..

Greene, T.J., Carroll, A.R., Hendrix, M.S., Graham, S.A., Wartes, M.A., Abbink, O.A., 2001, Sedimentary record of Mesozoic deformation and inception of the Turpan-Hami basin, northwest China, In: Hendrix, M.S., Davis, G.A. (Eds.), Paleozoic and Mesozoic tectonic evolution of central Asia - From continental assembly to intracontinental deformation. Geological Society of America, Memoir 194, 317-340.

Halls, H.C., 1978. The use of converging remagnetization circles in paleomagnetism. Physics of the Earth and Planetary Interiors 16, 1-11. 
Hankard, F., Cogne, J.-P., Quidelleur, X., Bayasgalan, A., Lkhagvadorj, P., Kravchinsky, V., 2007. Palaeomagnetism and K-Ar dating of Cretaceous basalts from Mongolia. Geophysical Journal International 169, 898-908

Hendrix, M.S., 2000. Evolution of Mesozoic sandstone compositions, southern Junggar, northern Tarim, and western Turpan basins, northwest China: a detrital record of the ancestral Tian Shan. Journal of Sedimentary Research 70, 520-532.

Hendrix, M.S., Graham, S.A., Carroll, A.R., Sobel, E.R., McKnight, C.L., Schulein, B.J., Wang, Z., 1992. Sedimentary record and climatic implications of recurrent deformation in the Tian Shan: Evidence from Mesozoic strata of the north Tarim, south Junggar, and Turpan basins, northwest China. Geological Society of America Bulletin 104, 53-79.

Hoffman, K.A., Day, R., 1978. Separation of multi-component NRM: a general method. Earth and Planetary Science Letters 40, 433-438.

Hrouda, F., 1982. Magnetic anisotropy of rocks and its application in geology and geophysics, Geophysical Surveys 5, 37-82.

Jelinek, V., 1978. Statistical processing of anisotropy of magnetic susceptibility measure on groups of specimens. Studia geophys. geod., 22, 50-62.

Jelinek, V., 1981. Characterization of the magnetic fabric of rocks. Tectonophysics 79, T63-T67.

Jolivet, M., Ritz, J-F., Vassalo, R., Larroque, C., Braucher, R., Todbileg, M., Chauvet, A., Sue, C., Arnaud, N., de Vicente, R., Arzhanikova, A., Arzhanikov, S., 2007. The Mongolian summits : An uplifted, flat, old but still preserved erosion surface. Geology 35, 871-874.

Jolivet, M., Dominguez, S., Charreau, J., Chen, Y., Li, Y., Wang, Q., 2010. Mesozoic and Cenozoic tectonic history of the Central Chinese Tian Shan : Reactivated tectonic structures and active deformation. Tectonics 29, TC6019, doi: 10.1029/2010TC002712.

Kirschvink, J.L., 1980. The least squares line and the analysis of paleoamgnetic data. Geophysical Journal of the Royal Astronomical Society 62, 699-718. 
Laurent-Charvet, S., Charvet, J., Monié, P., Shu, L.S., 2003. Late Paleozoic strike-slip shear zones in eastern central Asia (NW China): New structural and geochronological data. Tectonics 22, 1,0091,034 .

Laurent-Charvet, S., Charvet, J., Shu, L., Ma, R., Lu, H., 2002. Paleozoic late collisional strike-slip deformations in Tianshan and Altay, Eastern Xinjiang, NW China. Terra Nova 14, 249-256.

Lawrence, S.R., 1990. Aspects of the petroleum geology of the Junggar basin, Northwest China, In: Brooks, J. (Ed.), Classic Petroleum Provinces. The Geological Society, London, Special Publication 50, pp. 545-557.

Levashova, N.M., Degtyarev, K.E., Bazhenov, M.L., Collins, A.Q., van der Voo, R., 2003. Middle paleozoic paleomagnetism of east Kazakhstan: post-Middle Devonian rotations in a large-scale orocline in the central Ural-Mongol belt. Tectonophysics 377, 249-268.

Li, P., Zhang, Z., Wu, S., 1986. Stratigraphy, in: Permian and Triassic strata and fossil assemblages in the Dalongkou area of Jimsar, Xinjiang, People's Republic of China, Ministry of Geology and Mineral Resssources, Geology Memoir 3, pp. 2-38 (in Chinese).

Li, Y.P., Sharps, R., McWilliams, M., Li, Y. G., Li, Q., Zhang, W., 1991. Late Paleozoic paleomagnetic results from the Junggar Block, Northwestern China. Journal of Geophysical Research 96, 16047-16060.

Li, Z., Song, W.J., Peng, S.T., Wang, D.X., Zhang, Z.P., 2004. Mesozoic-Cenozoic tectonic relationships between the Kuqa sub-basin and Tian Shan, northwest China: constraints from depositional records. Sedimentary Geology 172, 223-249.

Liu, S., 1994. The non-marine Permian-Triassic boundary and Triassic Conchostracan fossils in China. Albertiana 13, 12-24.

McElhinny, M.W., 1964. Statistical significance of the fold test in paleomagnetism. Geophysical Journal of the Royal Astronomical Society 8, 338-340.

McFadden, P.L., 1990. A new fold test for paleomagnetic studies. Geophysical Journal International 103, 163-169. 
McFadden, P.L., Ma, X.H., McElhinny, M.W., Zhang, Z.K., $1988 . \quad$ Permo-Triassic magnetostratigraphy in China: northern Tarim. Earth and Planetary Science Letters 87, 152-160.

McFadden, P.L., McElhinny, M.W., 1988. The combined analysis of remagnetization circles and direct observations in paleomagnetism. Earth and Planetary Science Letters 87, 152-160.

McFadden, P.L., McElhinny, M.W., 1990. Classification of the reversal test in paleomagnetism. Geophysical Journal International 103, 725-729.

McKnight, C.L., Carroll, A.R., Chu, J., Hendrix, M.S., Graham, S.A., Lyon, R.J.P., 1989. Stratigraphy and structure of the Kalpin uplift, Tarim basin, northwest China, in: Proceedings, Seventh Thematic Conference on Remote Sensing for Exploration Geology, Calgary, Alberta: Ann Arbor, Environmental Research Institute of Michigan, 1085-1096.

Melnikov, A., Delvaux, D., Travin, A., Buslov, M., Vladimirov, A.,Smirnova, L., Theunissen, K., 1997. Late Paleozoic-earlymesozoic sinistral movement along the Irtysh shear zone, NE Kazakhstan. Tectonic studies group annual general meeting, Durham, 17-19 December.

Melnikov, A., Travin, A., Plotnikov, A., Smirnova, L., Theunissen, K., 1998. Kinematics and Ar/Ar geochronology of the Irtysh shear zone in NE Kazakhstan. In: Continental growth in the Phanerozoic: evidence from East-Central Asia. First workshop, IGCP-420, Urumqi, China, 27 July3 August, p. 30.

Metcalfe, I., Foster, C.B., Afonin, S.A., Nicoll, R.S., Mundil, R., Wang, X.F., Lucas, S.G., 2009. Stratigraphy, biostratigraphy and C-isotopes of the Permian-Triassic non-marine sequence at Dalongou and Lucaogou, Xinjiang Province, China. Journal of Asian Earth Science 36, 503-520.

Molnar, P., Tapponnier, P., 1975. Cenozoic tectonics of Asia: Effects of a continental collision. Science 189, 419-426.

Molnar, P., Tapponnier, P., 1977.Active Faulting and tectonics of China. Journal of Geophysical Research 82, 2905-2930.

Natal'in, B.A., Sengör, A.M.C., 2005. Late Palaeozoic to Triassic evolution of the Turan and Scythian platforms: The pre-history of the Palaeo-Tethyan closure. Tectonophysics 404, 175-202. 
Nie, S.Y., Rowley, D.B., van der Voo, R., Li, M.S., 1993. Paleomagnetism of Late Paleozoic rocks in the Tianshan, Northwestern China. Tectonics 12, 568-579.

Nishidai, T., Berry, J.L., 1990, Structure and hydrocarbon potential of the Tarim basin (NW China) from satellite imagery. Journal of Petroleum Technology 13, 35-58.

Ouyang, S., Norris G., 1999. Earliest Triassic (Induan) spores and pollen from the Junggar Basin, Xinjiang, northwest China. Review of Paleobotany and Palynology 106, 1-56.

Searle, M.P., 1991. Geology and Tectonics of the Kakakoram Mountains. Wiley, New York, 358 pp..

Sengör, A.M.C., Natal'in, B.A., Burtman, V.S., 1993. Evolution of the Altaid tectonic collage and Paleozoic crustal growth in Eurasia. Nature 364, 299-307.

Sengör, A.M.C., Natal'in, B.A., 1996. Paleotectonics of Asia: fragments of a synthesis, In: Yin, A., Harrison, M. (Eds.), The Tectonic Evolution of Asia. Cambridge University Press, Cambridge, pp. 486-640.

Sharps, R., Li, Y.P., McWilliams, M., Li, Y.G., 1992. Paleomagnetic investigation of Upper Permian sediments in the South Junggar Basin. Journal of Geophysical Research 97, 1753-1765.

Shu, S., Wang, B., Zhu, W.B., Guo, L.S., Charvet, J., Zhang, Y., 2011. Timing of initiation of extension in the Tianshan, based on structural, geochemical and geochronological analyses of bimodal volcanism and olistostrome in the Bogda Shan (NW China). International Journal of Earth Sciences 100, 1647-1663.

Sobel, E.R., Dumitru, T.A., 1997. Thrusting and exhumation around the margins of the western Tarim basin during the India-Asia collision. Journal of Geophysical Research 102, 5043-5063.

Tang, G., Wang, Q., Wyman, D.A., Li, Z.X., Zhao, Z.H., Jia, X.H., Jiang, Z.Q., 2010. Ridge subduction and crustal growth in the Central Asian Orogenic Belt: evidence from Late Carboniferous adakites and high-Mg diorites in the western Junggar region, northern Xinjiang (west China). Chemical Geology 277, 281-300.

Tapponnier, P., Molnar, P., 1977. Active faulting and tectonics of China. Journal of Geophysical Research 82, 2905-2930. 
Travin, A.V., Boven, A., Plotnikov, A.V., Vladimirov, V.G., Theunissen, K., Vladimirov, A.G., Melnikov, A.I., Titov, A.V., 2001. ${ }^{40} \mathrm{Ar} /{ }^{39} \mathrm{Ar}$ dating of ductile deformation in the Irtysh shear zone (Eastern Kazakhstan). Geochemistry 12, 1347-1350.

Van der Voo, R., Levashova, N.M., Skrinnik, L.I., Kara, T.V., Bazhenov, M.L., 2006. Late orogenic, large-scale rotations in the Tien Shan and adjacent mobile belts in Kyrgyzstan and Kazakhstan. Tectonophysics 426, 335-360.

Vladimirov, A., Melnikov, A., Travin, A., Plotnikov, A., Smirnova, L., Theunissen, K., 1998. The Irtysh shear zone in NE Kazakhstan: kinematics and preliminar data on metamorphic conditions and Ar/Ar geochronology. In: Active tectonic continental basin, International Conference, Gent, April 30-May 2, 1998, p. 105.

Wang, B., Chen, Y., Zhan, S., Shu, L.S., Faure, M., Cluzel, D., Charvet, J., Laurent-Charvet, S., 2007. Primary Carboniferous and Permian paleomagnetic results from the Yili Block (NW China) and their implications on the geodynamic evolution of Chinese Tianshan Belt. Earth and Planetary Science Letters 263, 288-308.

Wang, B., Cluzel, D., Shu, L.S., Faure, M., Charvet, J., Chen, Y., Meffre, S., Jong, K.D., 2009a. Evolution of calc-alkaline to alkaline magmatism through Carboniferous convergence to Permian transcurrent tectonics, western Chinese Tianshan. International journal of Earth Science 98, 12751298.

Wang, B., Faure, M., Cluzel, D., Shu, L. S., Charvet, J., Meffre, S., Ma, Q., 2006. Late Paleozoic tectonic evolution of the northem West Chinese Tianshan Belt. Geodinamica Acta, 19, 237-247.

Wang, B., Jahn, B.M., Lo, C.H., Shu, L.S, Wu, C.Y., Li, K.S., Wang, F., 2011. Structural analysis and ${ }^{40} \mathrm{Ar} /{ }^{39} \mathrm{Ar}$ thermochronology of Proterozoic rocks in Sailimu area (NW China): Implication to polyphase tectonics of the North Chinese Tianshan, Journal of Asian Earth Sciences 42, 839-853.

Wang, Q.C., Li, S.J., Du, Z.L., 2009b. Differential uplift of the Chinese Tianshan since the Cretaceous: constraints from sedimentary petrography and apatite fission-track dating. International Journal of Earth Sciences 98, 1341-1363. 
Wartes, M.A., Carroll, A.R., Greene, T.J., 2002. Permian sedimentary record of the Turpan-Hami basin and adjacent regions, northwest China: Constraints on postamalgamation tectonic evolution. Geological Society of America Bulletin 114, 131-152.

Wei, R.Z., 2010. Geochemistry and chronology of the Laba intrusion in western Junggar, Xinjiang. Acta Petrologica et Mineralogica 29, 663-674 (in Chinese with English abstract).

Windley, B.F., Alexeiev, D., Xiao, W., Kröner, A., Badarch, G., 2007. Tectonic models for accretion of the Central Asian Orogenic belt. Journal of the Geological Society 164, 31-47.

Windley, B.F., Kröner, A., Gui, J., Qu, G., Li, Y., Zhang, C., 2002. Neoproterozoic to Paleozoic geology of the Altai orogen, NW China: new zircon age data and tectonic evolution. Journal of Geology 110, 719-737.

Wu, J.Y., Liu, C.D., 1989. Geological features of the Bayingol ophiolite complexes in North Tien Shan, Xinjiang, Acta Petrologica Sinica 2, 76-87 (in Chinese).

Xiao, W.J., Han, C.M., Yuan, C., Sun, M., Lin, S.F., Chen, H.L., Li, Z.L., Li, J.L., Sun, S., 2008. Middle Cambrian to Permian subduction-related accretionary orogenesis of North Xinjiang, NW China: implications for the tectonic evolution of Central Asia. Journal of Asian Earth Sciences 32, $102-117$.

Xiao, W.J., Huang, B.C., Han, C.M., Gun, S., Li, J.L., 2010. A review of the western part of the Altaids: A key to understanding the architecture of accretionary orogens. Gondwana Research 18, 253-273.

Xiao, W.J., Windley, B.F., Badarch, G., Sun, S., Li, J., Qin, K., Wang, Z., 2004. Paleozoic accretionary and convergent tectonics of the southern Altaids: implications for the growth of Central Asia. Journal of the Geological Society 161, 339-342.

Xiao, W.J., Windley, B.F., Yuan, C., Sun, M., Han, C.M., Lin, S.F., Chen, H.L., Yan, Q.R., Liu, D.Y., Qin, K.Z., Li, J.L., Sun, S., 2009. Paleozoic multiple subduction-accretion processes of the southern Altaids. American Journal of Science 309, 221-270. 
Yang, J., Qu, L., Zhou, H., et al., 1986. Stratigraphy, in: Permian and Triassic strata and fossil assemblages in the Dalongkou area of Jimsar, Xinjiang, People's Republic of China, Ministry of Geology and Mineral Resssources, Geology Memoir 2, 235 pp. (in Chinese).

Yin, A., Harrison, T.M., 2000. Geologic evolution of the Himalayan-Tibetan orogen. Annual Review of Earth and Planetary Sciences 28, 211-280.

Yin, A., Nie, S., 1996. A Phanerozoic palinspastic reconstruction of China and its neighboring regions, In: Yin, A., Harrison, M. (Eds.), The Tectonic Evolution of Asia. Cambridge University Press, Cambridge, pp. 442-485.

Yu, C., Jiang, Y., Liu, S., 1996. Jurassic sedimentary boundary between the Junggar and Turpan-Hami basins in Xinjiang. Sedimentary Facies and Palaeogeography 16, 48-54 (in Chinese).

Zhang, J., Xiao, W.J., Han, C.M., Ao, S.J., Yuan, C., Sun, M., Geng, H.Y., Zhai, G.C., Guo, Q.Q., Ma, C., 2011. Kinematics and age constraints of deformation in a Late Carboniferous accretionary complex in Western Junggar, NW China. Gondwana Research 19, 958-974.

Zhao, J.M., Liu, G.D., Lu, Z.X., Zhang, X.K., Zhao, G.Z., 2003. Lithospheric structure and dynamic processes of the Tianshan orogenic belt and the Junggar basin, Tectonophysics 376, 199-239.

Zhou, D., Graham, S.A., Chang, E.Z., Wang, B., Hacker, B., 2001. Paleozoic tectonic amalgamation of the Chinese Tian Shan: Evidence from a transect along the Dushanzi-Kuqa Highway, In: Hendrix, M.S., Davis, G.A. (Eds.), Paleozoic and Mesozoic tectonic evolution of central AsiaFrom continental assembly to intracontinental deformation. Geological Society of America, Memoir 194, pp. 23-46.

Zhu, R., Yang, Z., Wu, H., Ma, X., Huang, B., Meng, Z., Fang, D., 1998. Paleomagnetic constraints on the tectonic history of the major blocks of China during the Phanerozoic. Science in China, Series D 41, 1-19 (in Chinese).

Zijderveld, J.D.A., 1967. AC demagnetization of rocks: analysis of results. In: Collinson, D.W., Creer, K.M., Runcorn, S.K. (Eds.), Methods on Paleomagnetism. Elsevier, pp. 245-286.

Zonenshain, L.P., Kuzmin, M.I., and Natapov, L.M., 1990. Geology of the USSR: A plate tectonic synthesis. AGU, Washington, D.C., Geodynamics Series Monograph 21. 242 p. 
Table and figure captions

Table 1. Results of the palaeomagnetic measurements. Abbreviations: n: number of measured samples; $\mathrm{N}$ : number of collected samples; Dg, Ig, Ds, and Is: declination (D) and inclination (I) in geographic (g) and stratigraphic (s) coordinates; $\mathrm{k}$, precision parameter; a95; radius of the $95 \%$ confidence circle. Types of demagnetisation: g: great circles, k: principal component analysis and s: stable point. See text for further explanations and references of methodology. *: for the Upper Triassic rocks from Urumqi, the palaeomagnetic mean direction of HTC is computed from specimen data instead of site-mean data. This result was excluded of tectonic interpretations.

Table 2. Compilation of palaeomagnetic data of Junggar, Tarim, and Siberia over the Early Mesozoic period. Abbreviations: N: number of sites; Slat (Plat): latitude of site (pole); Slong (Plong): longitude of site (pole); A95: radius of the $95 \%$ confidence circle. ${ }^{*}$ : The Upper Triassic pole for Tarim is expected from Gilder et al. (2008).

Table 3. Compilation of the Late Palaeozoic relative movements between South Junggar, West Junggar, Siberia, and Tarim; ANG \pm DANG, ROT \pm DROT and PLAT \pm DPLAT correspond to the angular difference between the palaeopoles, the relative rotation and the latitudinal displacement (and their error limit) between the blocks, respectively. Errors were computed by using the conversion factor of 0.78 (Demarest, 1983; Coe et al., 1985). The relative movements between the blocks are computed by using an average site at $44^{\circ} \mathrm{N}, 87^{\circ} \mathrm{E}$ for the Junggar block. A clockwise (counterclockwise) rotation relate to a positive (negative) ROT value. A positive (negative) value of Plat corresponds to a convergence (divergence) between the two blocks. Abbreviations: JG: Junggar; SJG: South Junggar; SIB: Siberia; TAR: Tarim; WJG: West Junggar.

Figure 1. a: Map of Eurasia, including the major domains with age. The grey curve structure represents the trend of the Kazakh Orocline, which encompasses West Junggar and North Tian Shan, b: Map of Northwestern China and neighbouring areas. Abbreviations: CANTF: Chingiz-Alakol-North Tianshan Fault, DF: Dalabute Fault, FF: Fuyun Fault, IGSZ: Irtysh-Gornotsaev Shear Zone, KF: 
Kelameili Fault, MTL: Main Tianshan Fault, NNTL: Nalati-Nikolaiev Tectonic Line, STF: South

Tianshan Fault. Location of figures 2 and 3 is also reported.

Figure 2. a: Geological map of North Tian Shan including the location of the three collected sections and data available in the literature, b: detailed geological map of Urumqi and Tien Shi areas, c: detailed geological map of Jimusar area, d: detailed geological map of Aiwergou area. All maps are adapted from BGRMXUAR (1993).

Figure 3. a: Geological map of West Junggar, including the location of the Laba area and data available in the literature, b: detailed geological map of the Laba area.

Figure 4 Synoptic table of the Upper Permian and Triassic formations of Northwestern China. The stratigraphic position of each collected section is also reported.

Figure 5 Picture's plate of the sampling localities. a: Lower Triassic redbeds from Urumqi, b: shallow dipping Upper Triassic sandstone from Urumqi, c: Upper Permian reddish sandstones from Tianshi, d: steeply dipping variegated Upper Triassic sandstone, e: panoramic view of the unconformable shallow dipping Lower Triassic strata over the Upper Permian folded black turbidites at Aiwergou, f: alternation of well-grading conglomerate and fine-grained pink sandstone, Early Triassic, Aiwergou, g: northward view of the Lower Triassic Laba basin, with shallow dipping red strata, h: detailed view of Early Triassic redbeds of Laba.

Figure 6. Results of the thermomagnetic Curie temperature measurements carried out on the six sections. a: Urumqi (Lower Triassic), b: Urumqi (Upper Triassic), c: Tianshi, d: Jimusar, e: Aiwergou, f: Laba. HC (CC): heating (cooling) curve.

Figure 7. Results of the Isothermal Remanence of the Magnetism (IRM) measurements carried out on three out of the six sections. a: Urumqi (Upper Triassic), b: Jimusar, c: Aiwergou.

Figure 8 Hysterisis cycle showing the typical shape for the ferromagnetic minerals. Paramagnetic corrections have been applied to the loops, but the uncorrected loops are also shown in insert. a: Urumqi (Lower Triassic), b: Urumqi (Upper Triassic), c: Tianshi, d: Jimusar, e: Aiwergou, f: Laba.

Figure 9. AMS measurements for a: Urumqi (Upper Triassic), b: Jimusar, c: Aiwergou. Left: Stereoplots of $\mathrm{K}_{1}, \mathrm{~K}_{2}$ and $\mathrm{K}_{3}$ data (open symbols) and their means (filled symbols), after Jelinek 
(1978). Right: Plots of the anisotropy degree $\left(\mathrm{P}_{\mathrm{J}}\right)$ versus the anisotropy shape $(\mathrm{T})$ of the magnetic susceptibility are also displayed. $P_{\mathrm{J}}=\exp \left\{2\left[\left(\ln K_{1}-\ln K_{m}\right)^{2}+\left(\ln K_{2}-\ln K_{m}\right)^{2}+\left(\ln K_{3}-\ln K_{m}\right)^{2}\right]^{1 / 2}\right\}$, and $\mathrm{T}=2 \ln \left(\mathrm{K}_{2} / \mathrm{K}_{3}\right) / \ln \left(\mathrm{K}_{1} / \mathrm{K}_{3}\right)-1$ (Jelinek, 1981; Hrouda, 1982). $\mathrm{K}_{1}, \mathrm{~K}_{2}$ and $\mathrm{K}_{3}$ are the principal axes of the magnetic fabrics and $\mathrm{K}_{\mathrm{m}}$ is the average of them.

Figure 10. Stereoplots of the site-mean directions of the low temperature component (LTC) and the locality-mean direction. Open (closed) symbols represent upper (lower) hemisphere projections. Data are in geographic coordinates. a: Urumqi (Lower Triassic), b: Urumqi (Upper Triassic), c: Tianshi, d: Jimusar, e: Aiwergou, f: Laba. White stars represent the site-mean directions. For comparison, the grey stars and the grey diamonds indicate the respective positions of the poles referring to the Axial Centred Dipole Field (DF) and the Present Earth Field (PEF).

Figure 11. Representative thermal demagnetisation plots (a, d, e, f) and site-mean stereoplots (b, c, g, h) of the Lower (a to d) and the Upper (e to h) Triassic rocks from Urumqi. For the thermal demagnetisation plots, the open (closed) symbols correspond to the magnetisation end-points projected onto the vertical (horizontal) plane. For the stereoplots, the open (closed) symbols represent the upper (lower) hemisphere projections.

Figure 12 Representative thermal demagnetisation plots (a, b, e and f) and site-mean stereoplots (c, d, $\mathrm{g}$ and $\mathrm{h}$ ) of the Upper Permian rocks from Tianchi (a to d) and of the Upper Triassic rocks from Jimusar (e to h). For the thermal demagnetisation plots, the open (closed) symbols correspond to the magnetisation end-points projected onto the vertical (horizontal) plane. For the stereoplots, open (closed) symbols represent the upper (lower) hemisphere projections.

Figure 13. Representative thermal demagnetisation plots (a, b, c, f and g) and site-mean stereoplots (c, $\mathrm{d}, \mathrm{h}$ and i) of the Lower Triassic rocks from Aiwergou (a to e) and of the Lower Triassic rocks from Laba (e to i). Dotted circle of confidence in (d) and (e) indicates the excluded site DQ57 (see text and Table 1). For the thermal demagnetisation plots, the open (closed) symbols correspond to the magnetisation end-points projected onto the vertical (horizontal) plane. For the stereoplots, open (closed) symbols represent the upper (lower) hemisphere projections. 
Figure 14. (a-d) Equal-area projections of Late Palaeozoic - Mesozoic poles of West Junggar, South Junggar Tarim and Siberia (see table 3 for numerical values and details on calculation). The poles with the dotted circle of confidence were excluded from the discussion. The angular difference (AD) and the amount of relative rotation (rot) and latitudinal movement (N-S) between the blocks are also indicated. The open stars represent the sampling location. Each small circle centred on this location and passing through poles reveals large discrepancies in declination (subsequent rotation) and weak differences in palaeolatitude (subsequent N-S movements) of blocks. Abbreviations: JG: Junggar; SJG: South Junggar; SIB: Siberia; TAR: Tarim; URM: Urumqi; WJG: West Junggar.

Figure 15. Simplified map of the Late Palaeozoic belts (in blue) of Western Central Asia (modified after Choulet et al., 2011). This belts overlie an Early Palaeozoic basement (in green) and display a $180^{\circ}$ curvature. The cryptic suture of the Junggar basement (red dashes) is hidden below the Junggar and Alakol basin (in yellow). The Late Carboniferous to Permian strike-slip faults and their major kinematics are also displayed. Abbreviations: CANTSF: Chingiz-Alakol-North Tianshan Fault, CKF: Central Kazakhstan Fault, DF: Dalabute Fault, GF: Gornotsaev Fault, K: Karamay city, KZK: Kazakhstan, NNTL: Nalati-Nikolaiev Tectonic Line, NTS: North Tianshan, U: Urumqi city, WJG: West Junggar.

Figure 16. Synoptic chart illustrating the tectonic episodes experienced by Northwestern China. The major alluvial events recorded in the South Junggar basin correlates with the major tectonic episodes. The sketches (not to scale) of the relative displacements between West Junggar (WJG), South Junggar (SJG), Junggar (JG), Siberia (SIB) and Tarim (TAR) reveal that the postCarboniferous rotations were accommodated by late orogenic-transcurrent faulting due to successive oblique reactivations. 
Table 1

\begin{tabular}{|c|c|c|c|c|c|c|c|c|c|}
\hline Site & Strike/dip & $\mathrm{n} / \mathrm{N}$ & type & $\mathrm{Dg}$ & Ig & Ds & Is & $\mathrm{k}$ & $\alpha 95$ \\
\hline \multicolumn{10}{|c|}{ "URUMQI SECTION (LOWER TRIASSIC) } \\
\hline \multirow{2}{*}{ Mean LTC } & & $7 / 7$ & & 359.6 & 62.6 & & & 100.0 & 6.1 \\
\hline & & $7 / 7$ & & & & 342.5 & 43.2 & 3.8 & 36.0 \\
\hline DQ42 & $232 / 105$ & $4 / 8$ & $3 g, 1 \mathrm{k}$ & 351.8 & 48.3 & 352.0 & -48.6 & 340.8 & 6.8 \\
\hline DQ43 & $237 / 33$ & $7 / 8$ & $7 \mathrm{k}$ & 10.0 & 61.3 & 349.9 & 33.0 & 392.2 & 12.1 \\
\hline DQ44 & $222 / 30$ & $8 / 8$ & $8 \mathrm{k}$ & 9.3 & 68.0 & 338.3 & 44.5 & 20.3 & 18.3 \\
\hline DQ45 & $216 / 24$ & $7 / 7$ & $7 \mathrm{k}$ & 39.9 & 48.8 & 14.0 & 44.8 & 107.7 & 15.1 \\
\hline DQ46 & $220 / 24$ & $5 / 5$ & $5 \mathrm{k}$ & 50.6 & 57.5 & 14.4 & 54.2 & 25.5 & 13.4 \\
\hline DQ47 & $115 / 30$ & $6 / 8$ & $6 \mathrm{k}$ & 6.9 & 55.6 & 311.0 & 79.9 & 10.7 & 21.5 \\
\hline DQ48 & $43 / 35$ & $5 / 5$ & $5 \mathrm{k}$ & 358.1 & 59.2 & 71.6 & 65.6 & 11.0 & 24.1 \\
\hline \multirow{2}{*}{ Mean HTC } & & $7 / 7$ & & 15.3 & 58.7 & & & 34.2 & 10.5 \\
\hline & & $7 / 7$ & & & & 1.2 & 47.0 & 3.6 & 37.0 \\
\hline \multicolumn{10}{|c|}{ " URUMQI SECTION (UPPER TRIASSIC) } \\
\hline \multirow{2}{*}{ Mean LTC } & & $8 / 8$ & & 12.0 & 59.2 & & & 163.5 & 4.3 \\
\hline & & $8 / 8$ & & & & 12.5 & 53.2 & 7.1 & 22.3 \\
\hline \multirow{2}{*}{ Mean HTC* } & & $10 / 64$ & & 325.4 & 33.4 & & & 21.2 & 11.3 \\
\hline & & $10 / 64$ & & & & 325.8 & 49.0 & 59.5 & 6.7 \\
\hline \multicolumn{10}{|c|}{ TIANCHI SECTION (UPPER PERMIAN) } \\
\hline \multirow{2}{*}{ Mean LTC } & & $6 / 6$ & & 51.9 & 74.2 & & & 52.3 & 9.3 \\
\hline & & $6 / 6$ & & & & 6.9 & 47.3 & 79.7 & 7.6 \\
\hline DQ01 & $252 / 40$ & $5 / 5$ & $4 \mathrm{~g}, 1 \mathrm{k}$ & 71.2 & 75.7 & 3.6 & 47.7 & 59.3 & 12.5 \\
\hline DQ02 & $252 / 40$ & $5 / 5$ & $5 \mathrm{~g}$ & 271.3 & -73.8 & 187.8 & -52.7 & 0.0 & 12.4 \\
\hline DQ03 & $248 / 30$ & $4 / 5$ & $1 \mathrm{~g}, 3 \mathrm{k}$ & 295.5 & -82.1 & 170.8 & -65.3 & 65.1 & 12.2 \\
\hline DQ04 & $260 / 31$ & $5 / 5$ & $5 \mathrm{k}$ & 294.0 & -76.8 & 195.9 & -64.2 & 138.2 & 6.5 \\
\hline DQ05 & $260 / 30$ & $5 / 5$ & $3 \mathrm{~g}, 2 \mathrm{k}$ & 299.0 & -67.5 & 219.6 & -67.0 & 113.0 & 8.2 \\
\hline DQ06 & $262 / 35$ & $5 / 5$ & $3 \mathrm{~g}, 2 \mathrm{k}$ & 285.7 & -71.0 & 206.5 & -58.2 & 76.1 & 10.0 \\
\hline \multirow{2}{*}{ MeanHTC } & & $6 / 6$ & & 283.3 & -75.1 & & & 137.2 & 5.7 \\
\hline & & $6 / 6$ & & & & 192.9 & -60.0 & 52.4 & 9.3 \\
\hline \multicolumn{10}{|c|}{ 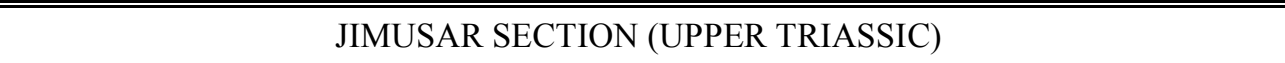 } \\
\hline \multirow{2}{*}{ MeanLTC } & & $5 / 6$ & & 18.5 & 64.8 & & & 52.7 & 10.6 \\
\hline & & $5 / 6$ & & & & 252.8 & 47.6 & 47.3 & 11.2 \\
\hline DQ66 & $145 / 65$ & $8 / 8$ & $8 \mathrm{k}$ & 219.0 & -17.9 & 167.4 & -73.5 & 65.8 & 6.9 \\
\hline DQ67 & $145 / 65$ & $8 / 8$ & $8 \mathrm{k}$ & 213.0 & -18.8 & 157.4 & -68.7 & 58.7 & 7.3 \\
\hline DQ68 & $145 / 65$ & $9 / 9$ & $1 \mathrm{~g}, 8 \mathrm{k}$ & 217.2 & -18.6 & 162.6 & -72.3 & 59.7 & 6.8 \\
\hline DQ69 & $136 / 55$ & $8 / 8$ & $8 \mathrm{k}$ & 209.4 & 0.3 & 198.8 & -51.4 & 88.6 & 5.9 \\
\hline DQ70 & $136 / 55$ & $10 / 10$ & $10 \mathrm{k}$ & 208.6 & -2.7 & 195.6 & -53.9 & 63.2 & 6.1 \\
\hline DQ71 & $139 / 60$ & $8 / 8$ & $2 \mathrm{~g}, 6 \mathrm{k}$ & 206.6 & -10.3 & 177.7 & -61.3 & 47.1 & 8.3 \\
\hline \multirow{2}{*}{ MeanHTC } & & $6 / 6$ & & 212.2 & -11.4 & & & 68.4 & 8.2 \\
\hline & & $6 / 6$ & & & & 181.1 & -64.4 & 44.1 & 10.2 \\
\hline
\end{tabular}


Mean LTC

DQ57

$120 / 2$

DQ58 135/22

DQ59 134/23

DQ60 118/30

DQ61 125/32

DQ62 125/32

DQ63 118/32

DQ64 115/38
$348.4 \quad 48.6$

Mean HTC
$7 / 9$

$6 / 7$

$6 / 9$

$5 \mathrm{~g}, 1 \mathrm{~s}, 1 \mathrm{k}$

$5 \mathrm{~g}, 1 \mathrm{k}$

$5 \mathrm{~g}, 1 \mathrm{k}$

$4 \mathrm{~g}, 1 \mathrm{k}$

$28.6-59.3-357.5$

$\begin{array}{llll}0.4 & 24.3 & 347.4 & 49\end{array}$

$172.1 \quad-33.8 \quad 146.3 \quad-52.6$

$\begin{array}{llll}181.3 & -35.8 & 155.2 & -58.7\end{array}$

$\begin{array}{llll}169.9 & -29.0 & 149.2 & -50.9\end{array}$

$4 \mathrm{~g}$

357.940 .0

$7 / 8$
359.175 .9

$358.8-53.8-323.2=64.9$

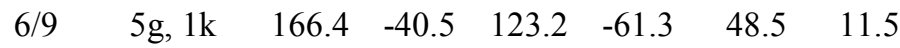

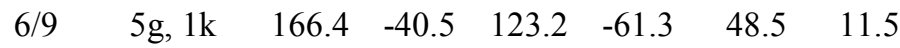

$123.6 \quad 5.0$

$28.4 \quad 12.7$

$44.2 \quad 12.1$

$19.4 \quad 18.3$

$40.6 \quad 15.1$

- $\quad 13.4$

- $\quad 19.2$

\begin{tabular}{l}
$-\quad 9.9$ \\
\hline
\end{tabular}

$26.4 \quad 12.0$

$7 / 8$

\begin{tabular}{llll}
330.3 & 60.3 & 40.1 & 9.6 \\
\hline
\end{tabular}

LABA SECTION (UNDIFFERENCIED TRIASSIC)

\begin{tabular}{|c|c|c|c|c|c|c|c|c|c|}
\hline \multirow{2}{*}{ Mean LTC } & & $5 / 8$ & & 6.0 & 58.3 & & & 274.9 & 4.6 \\
\hline & & $5 / 8$ & & & & 341.5 & 55.1 & 369.6 & 4.0 \\
\hline DQ07 & $185 / 10$ & $4 / 4$ & & \multicolumn{6}{|c|}{ excluded } \\
\hline DQ08 & $185 / 10$ & $4 / 4$ & & \multicolumn{6}{|c|}{ excluded } \\
\hline DQ09 & $210 / 20$ & $4 / 4$ & $4 \mathrm{k}$ & 177.0 & -62.4 & 155.7 & -48.3 & 12.6 & 27.0 \\
\hline DQ10 & $210 / 20$ & $7 / 7$ & 1g. $6 \mathrm{k}$ & 172.2 & -58.3 & 155.0 & -43.6 & 98.1 & 6.2 \\
\hline DQ11 & $185 / 22$ & $8 / 8$ & 1g. $7 \mathrm{k}$ & 223.5 & -74.8 & 139.4 & -72.9 & 171.5 & 4.3 \\
\hline DQ12 & $185 / 22$ & $4 / 4$ & $4 \mathrm{k}$ & 225.8 & -70.7 & 153.4 & -72.9 & 1750.1 & 2.2 \\
\hline DQ13 & $185 / 22$ & $5 / 5$ & $5 \mathrm{k}$ & 224.1 & -80.6 & 145.6 & -80.5 & 27.0 & 15.0 \\
\hline DQ14 & $185 / 15$ & $5 / 8$ & 1g. $4 \mathrm{k}$ & 190.0 & -74.9 & 143.6 & -69.8 & 46.2 & 11.7 \\
\hline \multirow{2}{*}{ Mean HTC } & & $6 / 8$ & & 195.2 & -71.8 & & & 46.8 & 9.9 \\
\hline & & $6 / 8$ & & & & 151.0 & -64.9 & 28.4 & 12.8 \\
\hline
\end{tabular}


Table 2

\begin{tabular}{llcccccccl}
\hline Block & Locality & Age & N & Slat & Slong & Plat & Plong & $A_{95}$ & Reference \\
\hline \multirow{2}{*}{ West Junggar } & Mean & P2 & 3 & 45.5 & 84.4 & 53.0 & 183.9 & 16.6 & Choulet et al., 2011 \\
& Laba & T1 & $\mathbf{6}$ & $\mathbf{4 5 . 4}$ & $\mathbf{8 3 . 1}$ & $\mathbf{6 9 . 9}$ & $\mathbf{7 . 7}$ & $\mathbf{2 0 . 6}$ & This study \\
\multirow{5}{*}{ South Junggar } & Mean & C3-P & 6 & 43.8 & 87.8 & 77.0 & 7.6 & 9.9 & Choulet et al., 2011 \\
& Tianchi & P2 & $\mathbf{6}$ & $\mathbf{4 3 . 9}$ & $\mathbf{8 8 . 1}$ & $\mathbf{8 0 . 0}$ & $\mathbf{1 9 1 . 6}$ & $\mathbf{1 2 . 4}$ & This study \\
& Aiwergou & T1 & $\mathbf{7}$ & $\mathbf{4 3 . 0}$ & $\mathbf{8 7 . 5}$ & $\mathbf{6 8 . 0}$ & $\mathbf{3 . 0}$ & $\mathbf{1 4 . 6}$ & This study \\
\multirow{5}{*}{ Junggar } & & & & & & & & & \\
& Jimusar & T3 & $\mathbf{6}$ & $\mathbf{4 3 . 8}$ & $\mathbf{8 9 . 2}$ & $\mathbf{8 7 . 5}$ & $\mathbf{1 0 6 . 2}$ & $\mathbf{1 3 . 1}$ & This study \\
& Junggar & J3-K1 & 13 & 44.2 & 86.0 & 72.3 & 227.3 & 4.8 & Chen et al., 1991 \\
& Junggar & K2-Cz1 & 9 & 44.2 & 86.0 & 74.3 & 223.1 & 1.9 & Chen et al., 1991 \\
& Urumqi & Cz & $\mathbf{7}$ & $\mathbf{4 3 . 8}$ & $\mathbf{8 7 . 8}$ & $\mathbf{7 7 . 8}$ & $\mathbf{1 9 3 . 4}$ & $\mathbf{1 5 . 6}$ & This study \\
& & & & & & & & & \\
& Mearim & C3-T1 & & & & 63.4 & 181.0 & 6.2 & Gilder et al., 2008 \\
& West & & & & & & & & \\
& Tarim & T1 & 5 & 41.0 & 74.9 & 52.8 & 175.5 & 8.0 & Zhu et al., 1998 \\
& Mean & T3 & & & & 70.4 & 190.0 & 7.0 & Gilder et al., 2008* \\
& Aksu & T3 & 8 & 41.7 & 80.5 & 52.1 & 166.8 & 5.8 & Fang et al. 1990 \\
& Kuche & J2 & 6 & 42.1 & 83.2 & 75.7 & 198.0 & 8.1 & Gilder et al., 2008 \\
& & & & & & & & & \\
& Mean & P2 & 5 & & & 50.0 & 160.0 & 7.0 & Van der Voo, 1993 \\
& Mean & T1 & 9 & & & 52.0 & 156.0 & 4.0 & Van der Voo, 1993 \\
& Mean & T3 & 6 & & & 55.0 & 138.0 & 9.0 & Van der Voo, 1993 \\
\hline
\end{tabular}


Table 3

\begin{tabular}{|c|c|c|c|c|}
\hline Age & Blocks & $\mathrm{ANG} \pm \Delta \mathrm{ANG}\left({ }^{\circ}\right)$ & $\mathrm{ROT} \pm \Delta \mathrm{ROT}\left({ }^{\circ}\right)$ & $\operatorname{PLAT} \pm \Delta \operatorname{PLAT}\left({ }^{\circ}\right)$ \\
\hline \multirow{3}{*}{$\mathrm{P} 2$} & SJG-TAR & $39.5 \pm 11.7$ & $-52.2 \pm 15.9$ & $-7.6 \pm 9.3$ \\
\hline & SJG-SIB & $51.8 \pm 12.1$ & $-73.9 \pm 16.8$ & $-2.4 \pm 9.7$ \\
\hline & SJG-WJG & $50.0 \pm 19.2$ & $-62.1 \pm 23.7$ & $-4.2 \pm 15.5$ \\
\hline \multirow{3}{*}{$\mathrm{T} 1$} & SJG-TAR & $48.6 \pm 12.7$ & $-63.3 \pm 16.6$ & $-5.0 \pm 10.2$ \\
\hline & SJG-SIB & $58.3 \pm 11.8$ & $-83.3 \pm 15.8$ & $3.4 \pm 9.4$ \\
\hline & SJG-WJG & $2.5 \pm 23.4$ & $-2.0 \pm 31.9$ & $-2.0 \pm 18.7$ \\
\hline \multirow{2}{*}{$\mathrm{T} 3$} & JG-TAR & $19.5 \pm 14.9$ & $-23.4 \pm 20.9$ & $-8.8 \pm 11.9$ \\
\hline & JG-SIB & $32.9 \pm 15.9$ & $-51.6 \pm 25.2$ & $10.9 \pm 12.7$ \\
\hline $\mathrm{J} 3-\mathrm{Cz} 1$ & JG-TAR & $7.7 \pm 8.4$ & $-7.6 \pm 9.6$ & $-3.8 \pm 6.7$ \\
\hline \multicolumn{3}{|c|}{ Blocks } & \multicolumn{2}{|c|}{$\mathrm{ROT} \pm \Delta \mathrm{ROT}\left({ }^{\circ}\right)$} \\
\hline \multicolumn{3}{|c|}{ SJG-TAR (P2 to T1) } & \multicolumn{2}{|c|}{$11.1 \pm 17.9$} \\
\hline \multicolumn{3}{|c|}{ SJG-TAR (T1 to T3) } & \multicolumn{2}{|c|}{$-39.9 \pm 20.8$} \\
\hline \multicolumn{3}{|c|}{ SJG-TAR (T3 to J3-K1) } & \multicolumn{2}{|c|}{$-15.8 \pm 17.9$} \\
\hline \multicolumn{3}{|c|}{ SJG-SIB (P2 to T1) } & \multicolumn{2}{|c|}{$9.4 \pm 18.0$} \\
\hline \multicolumn{3}{|c|}{ SJG-SIB (T1 to T3) } & \multicolumn{2}{|c|}{$-31.7 \pm 23.2$} \\
\hline
\end{tabular}




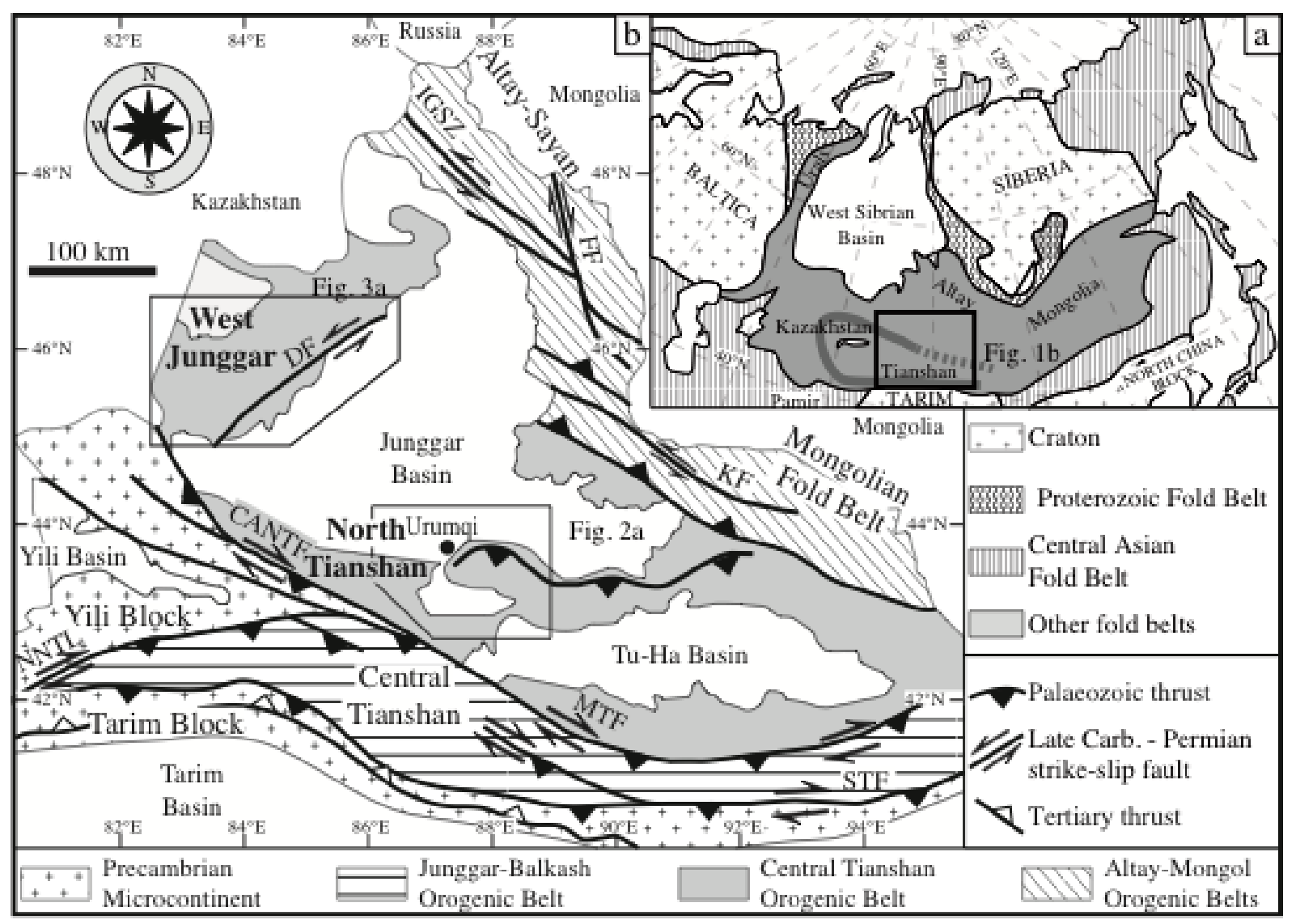

Figure 1 

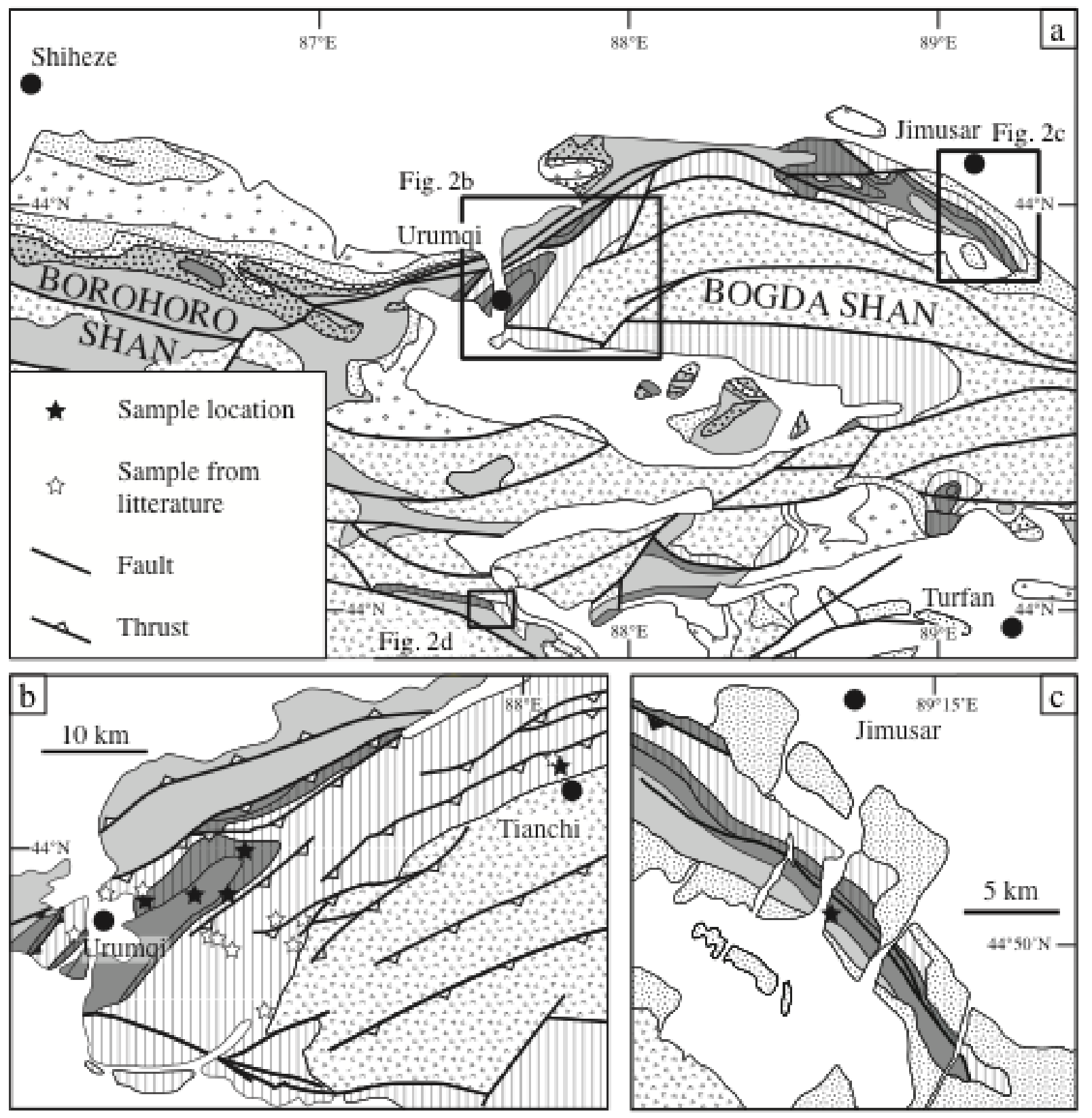

\begin{tabular}{|c|c|c|}
\hline & Recent Quaternary & Jurassic \\
\hline$E$ & Quaternary & Upper Triassic \\
\hline & Upper Cenozoic & Lower Triassic \\
\hline 蹗逆 & Lower Cenozoic & Permian \\
\hline 唡圈 & Cretaceous & Palaeozoic \\
\hline
\end{tabular}

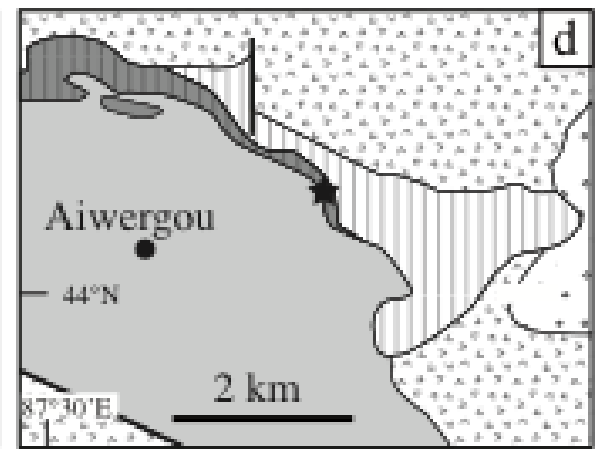




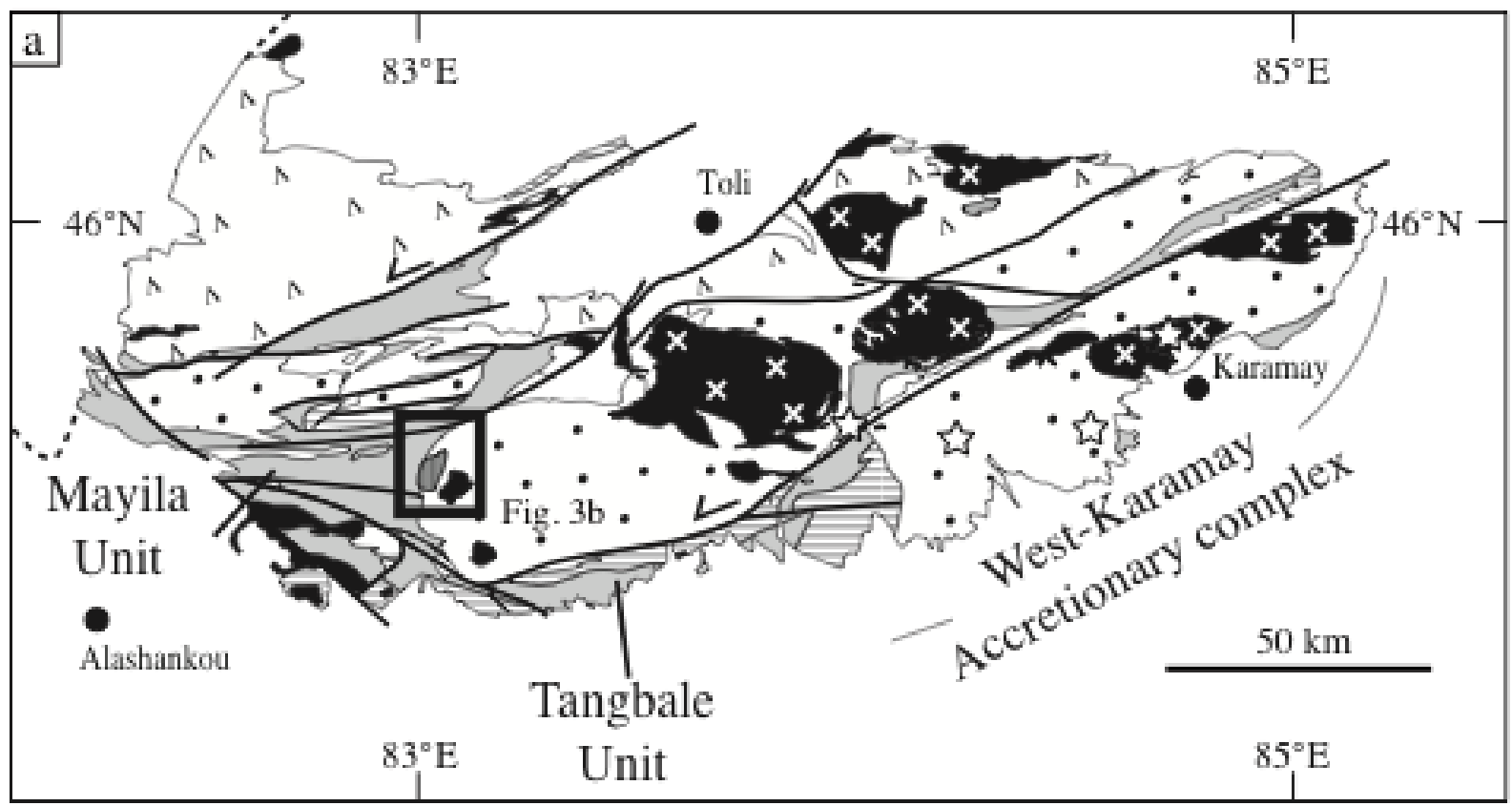

\begin{tabular}{|c|c|}
\hline & Fault \\
\hline & Sample location \\
\hline$\hat{\Lambda}$ & Sample from \\
\hline & litterature \\
\hline & Lower Triassic \\
\hline$x \times$ & $\begin{array}{l}\text { Post-accretionnary } \\
\text { plutons }(310-250 \mathrm{Ma})\end{array}$ \\
\hline 12 & Ophiolitic mélanges \\
\hline$\because \cdot$ & $\begin{array}{l}\text { Late Palacozoic } \\
\text { Accretionary Complex }\end{array}$ \\
\hline $\mathrm{A} \mathrm{A}$ & Late Palacozoic are volcanics \\
\hline & Early Palacozoic \\
\hline & Accretionary Complexes \\
\hline
\end{tabular}

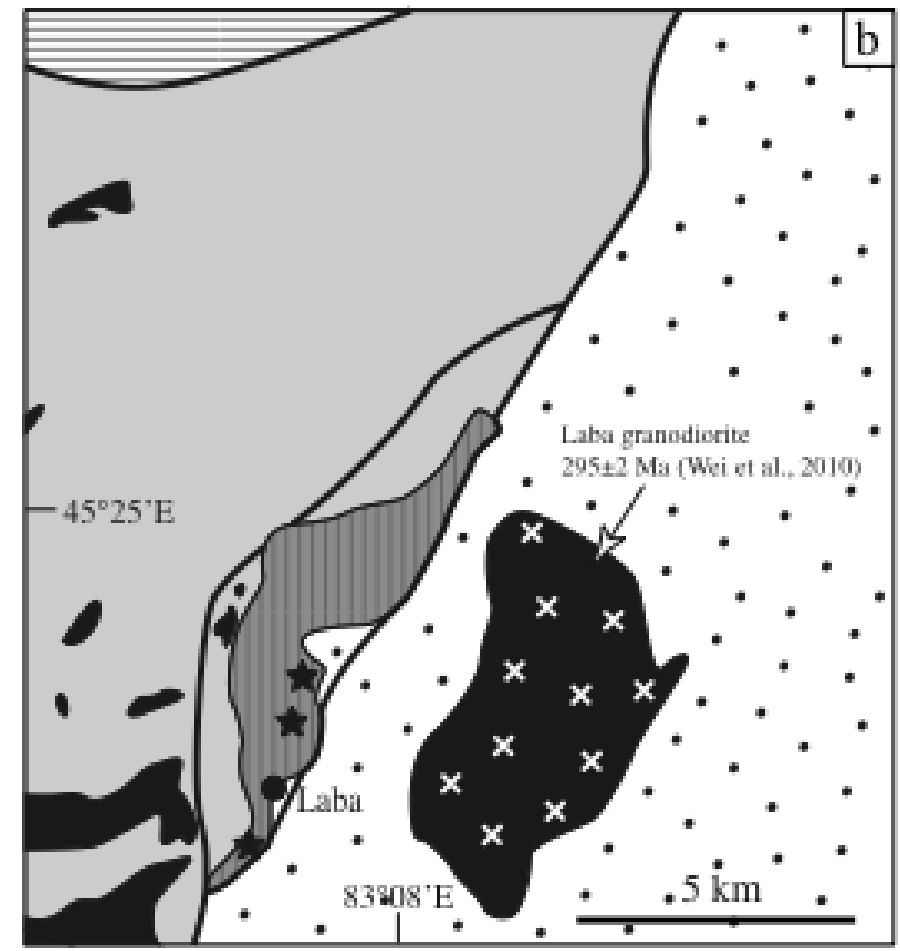

Figure 3 


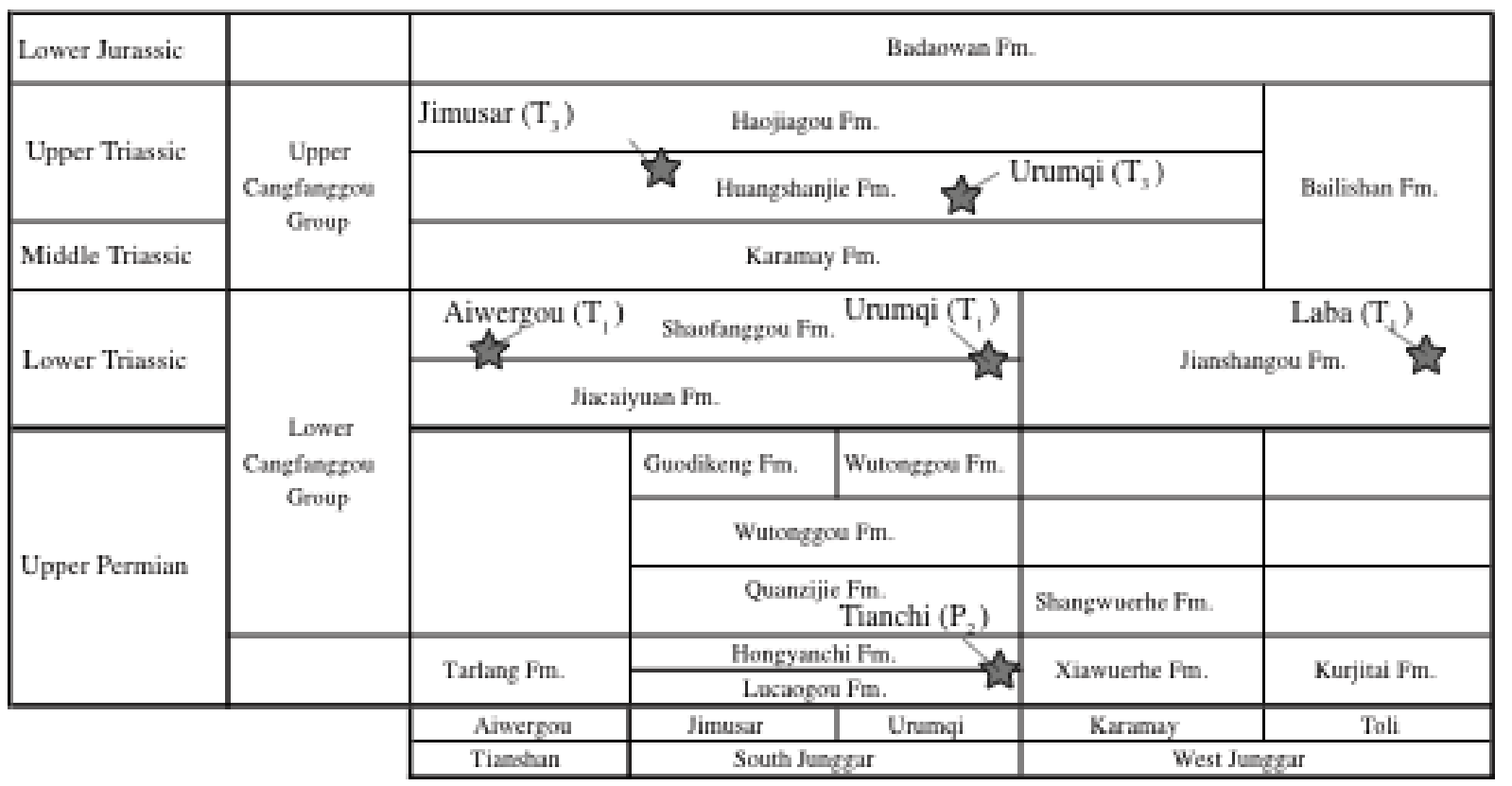

Figure 4 

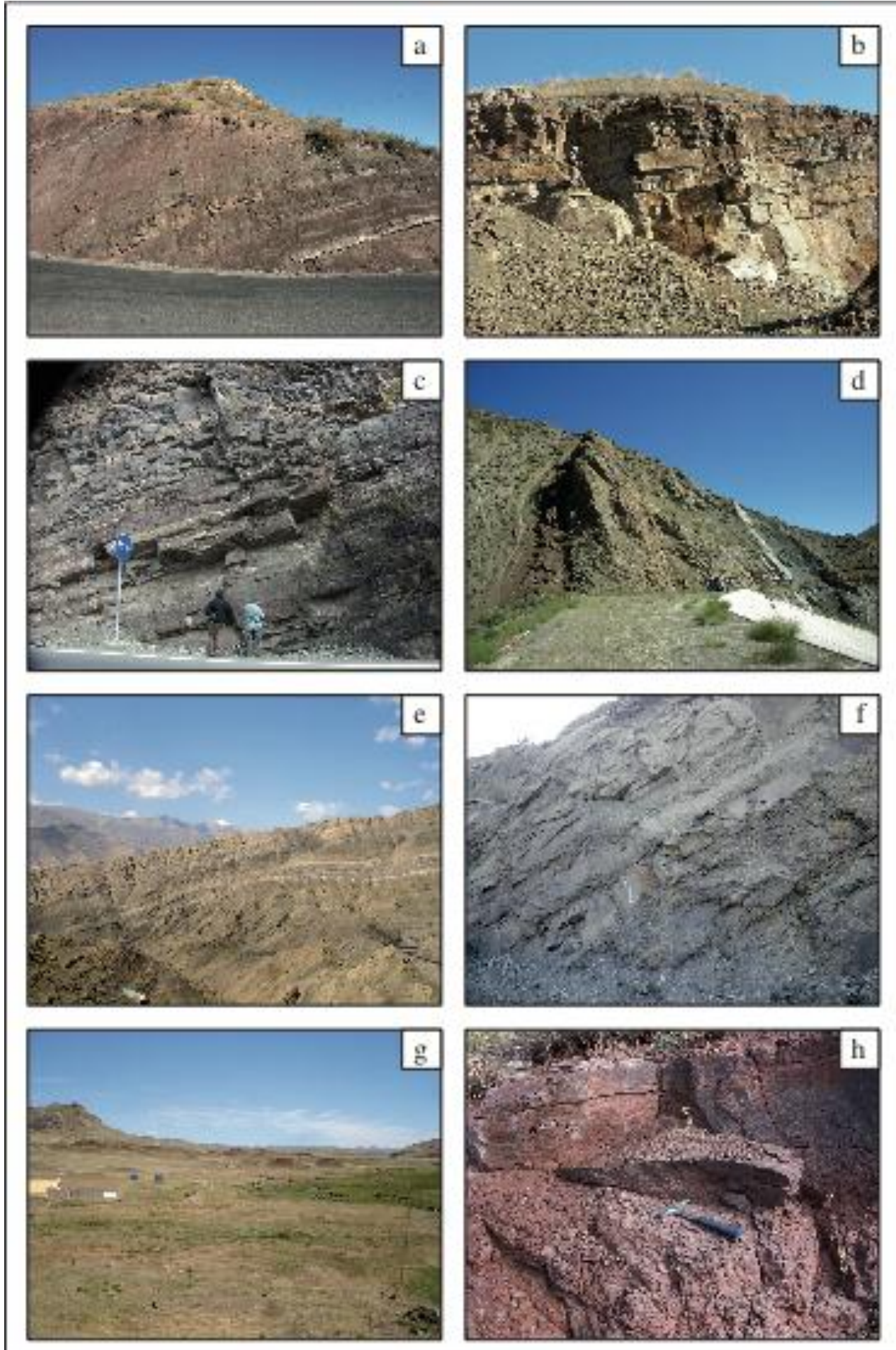

Figure 5 


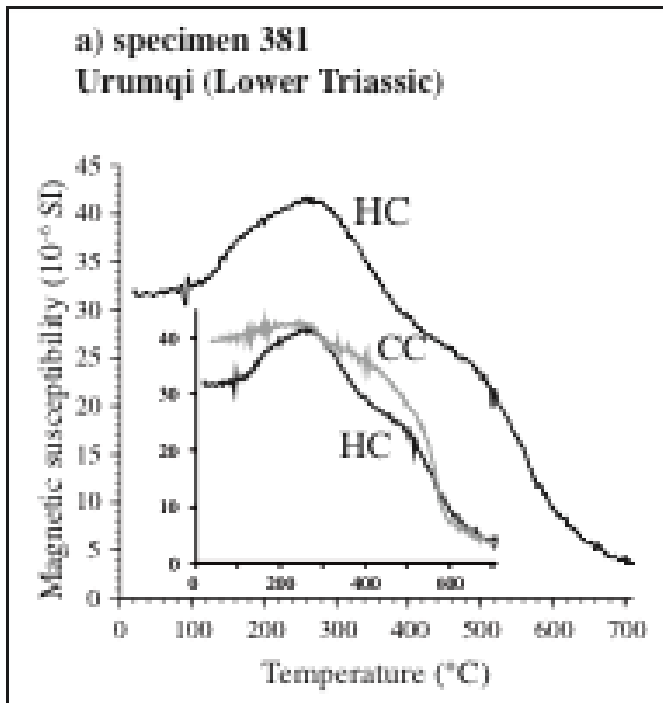

c) specimen $03-10 \mathrm{~A}$

Tianchi (Upper Permian)

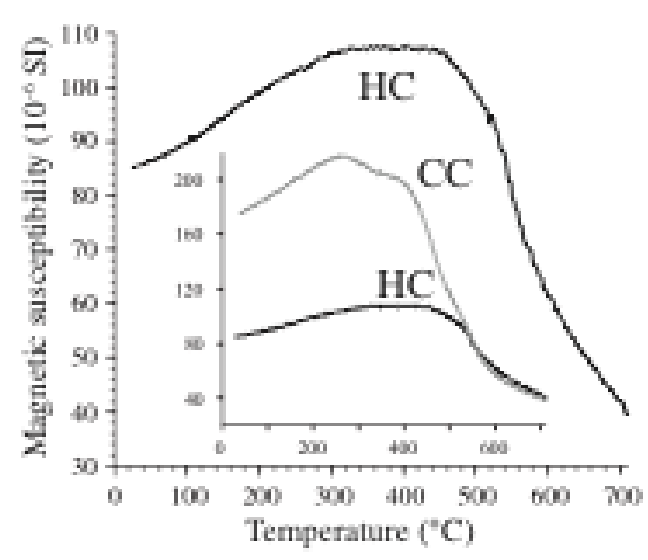

e) specimen $523 \mathrm{~A}$

Aiwergou (Lower Triassic)

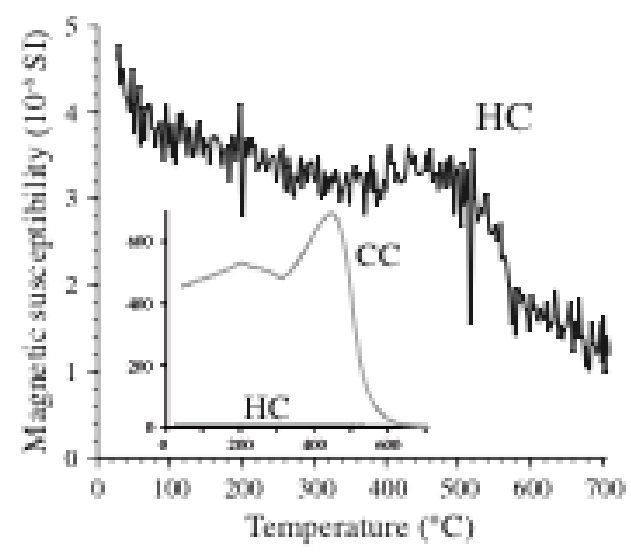

b) specimen 350

Urumqi (Upper Triassic)

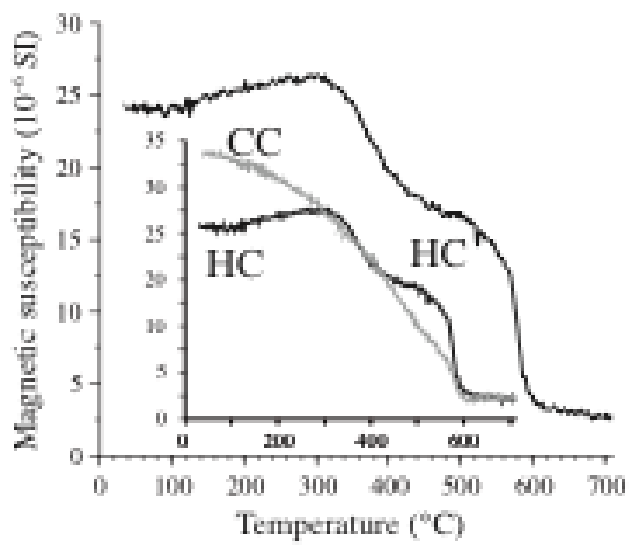

d) specimen $609 \mathrm{~A}$

Jimusar (Upper Triassic)

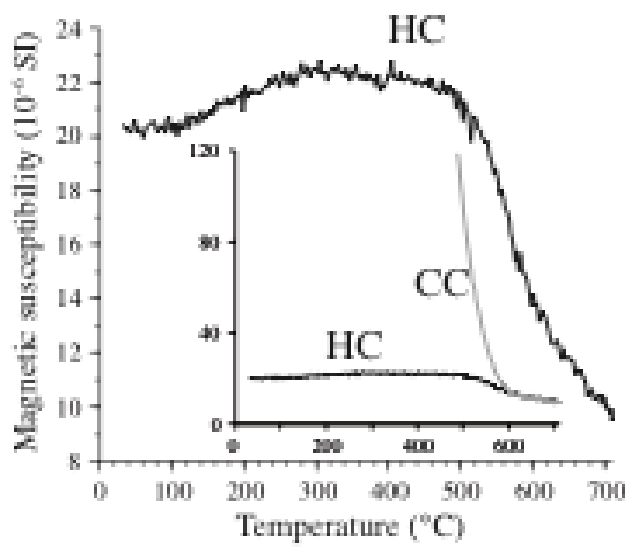

f) specimen 96

Laba (Lower Triassic)

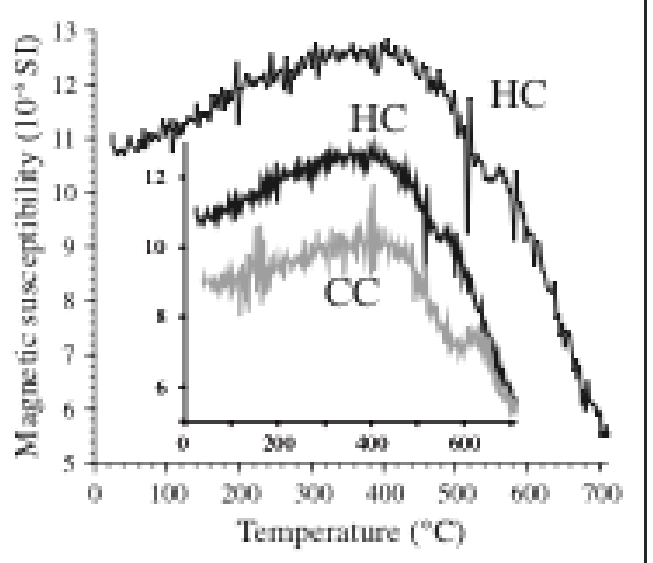

Figure 6 


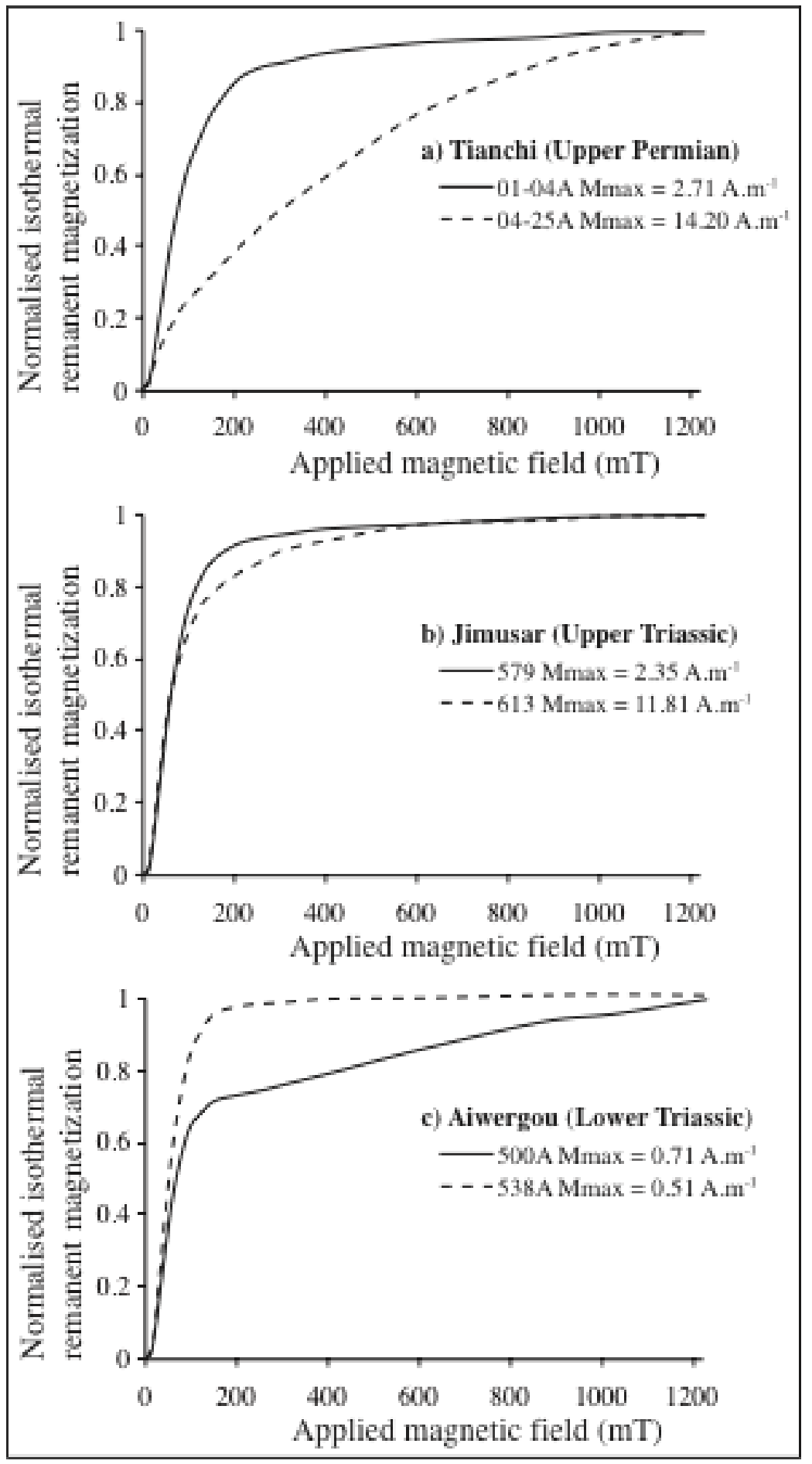

Figure 7 


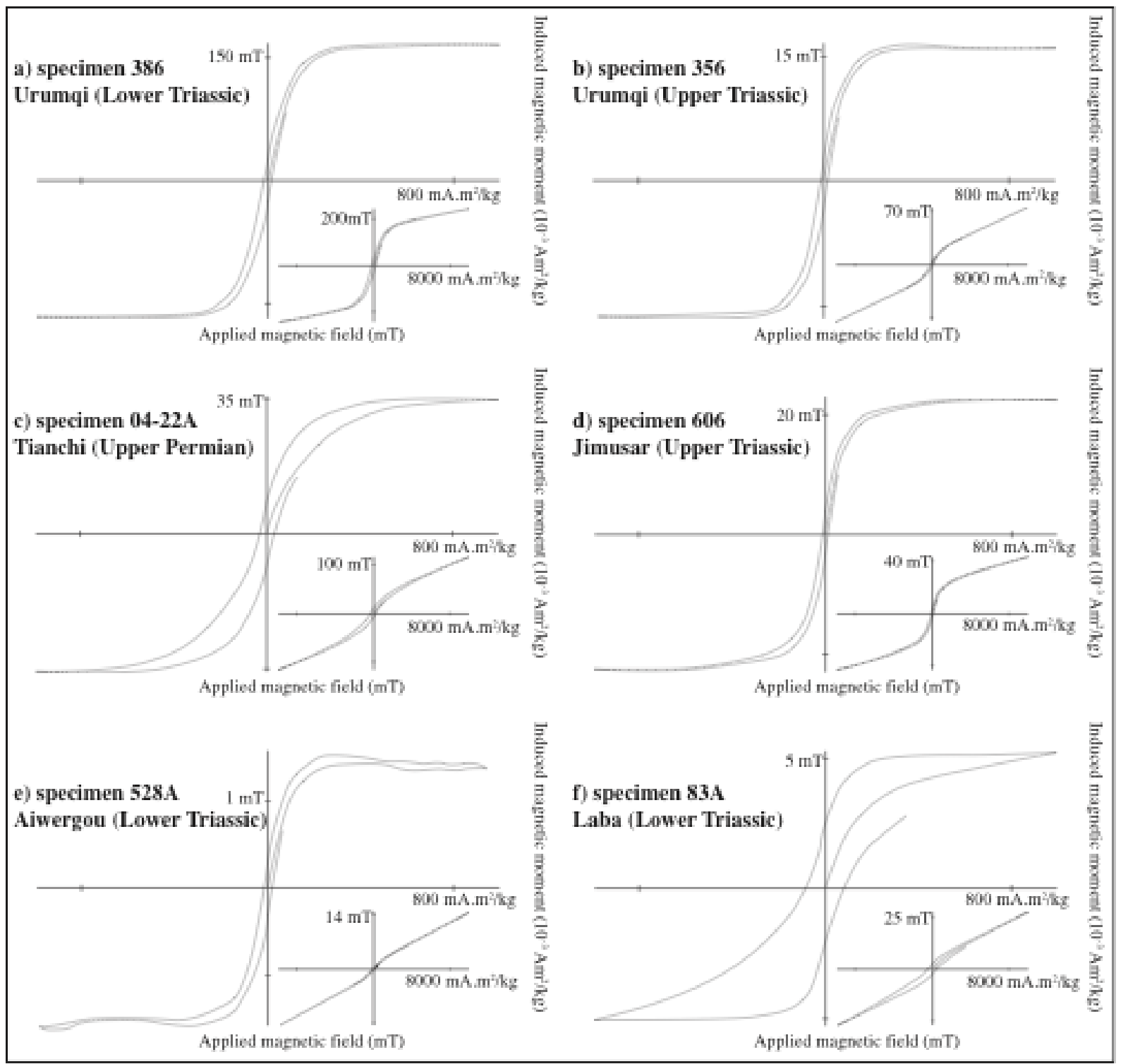

Figure 8 


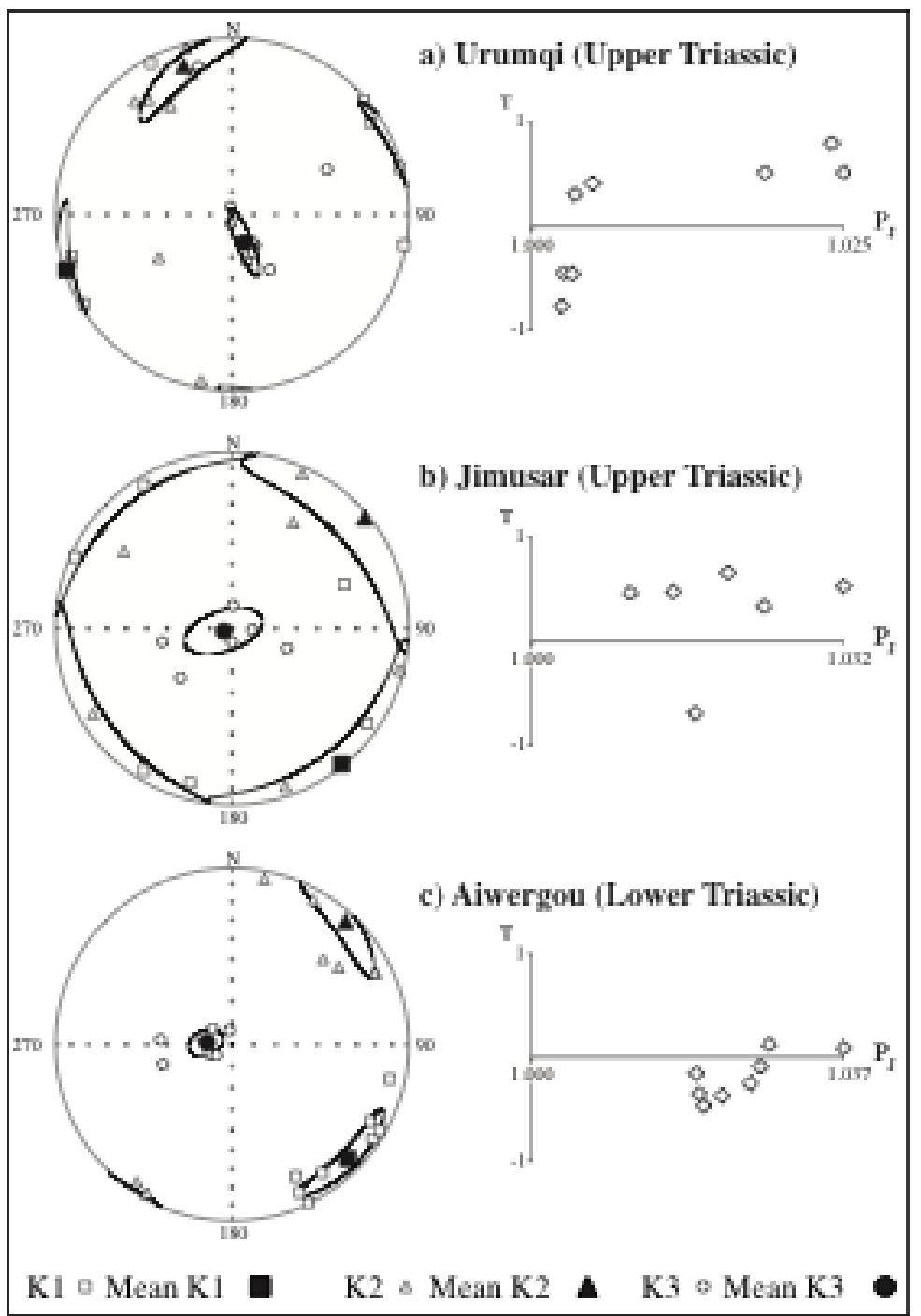

Figure 9 

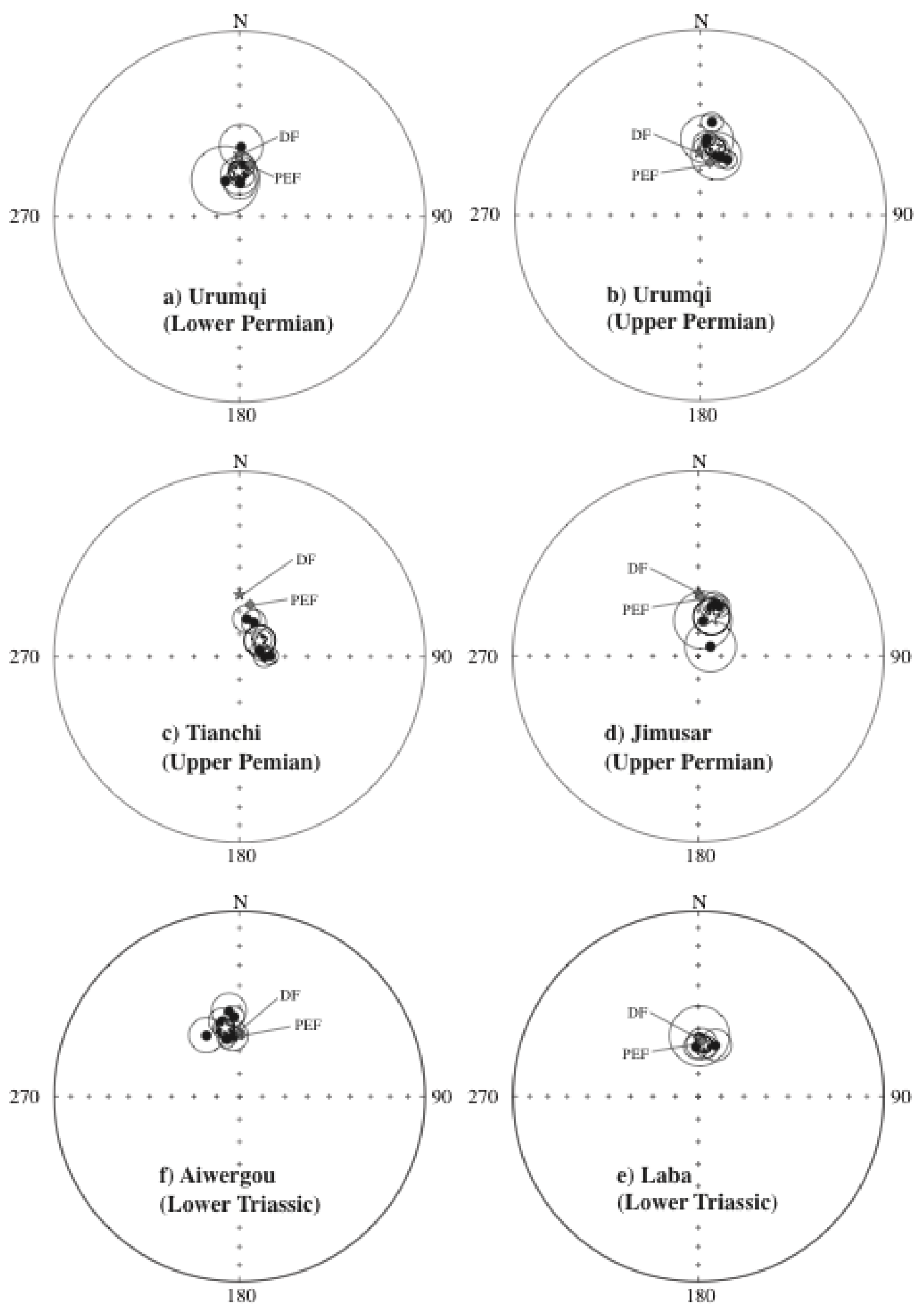

Figure 10 


\section{Urumqi (Lower Triassic)}

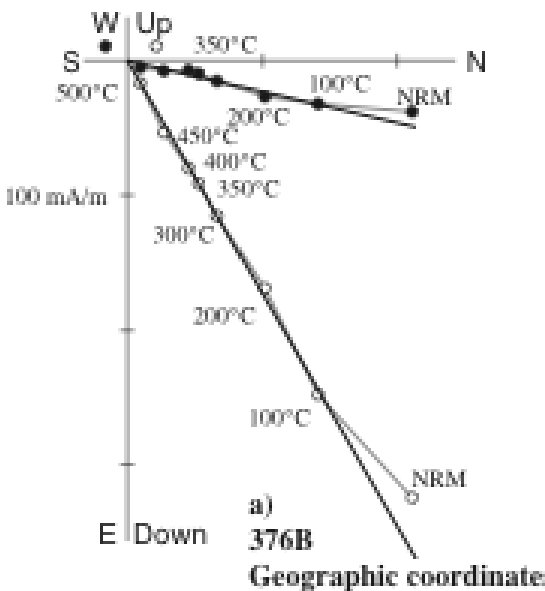

\section{Urumqi (Upper Triassic)}
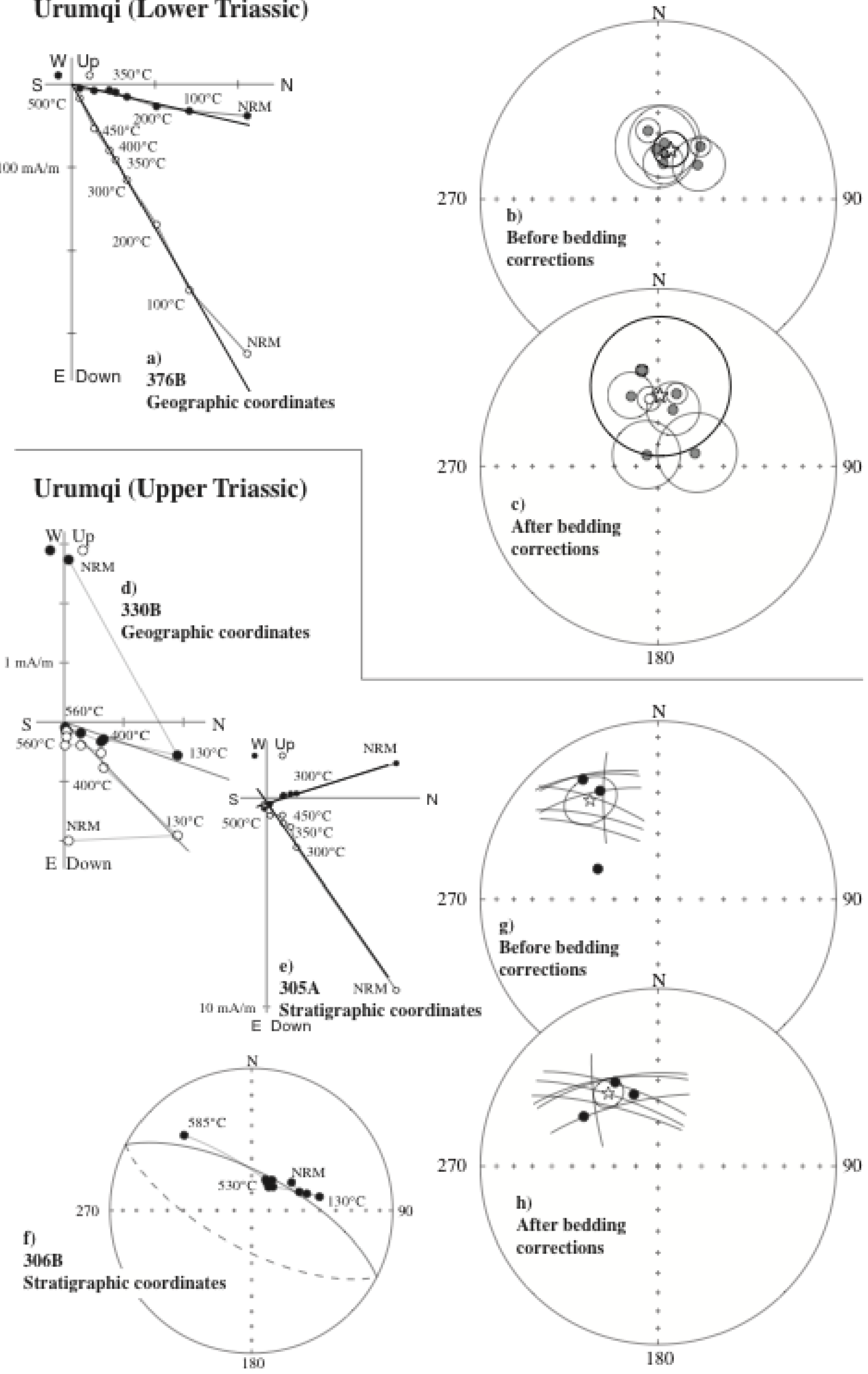

Figure 11 
Tianchi (Upper Permian)

a)

04-23B

Stratigraphic coordinates
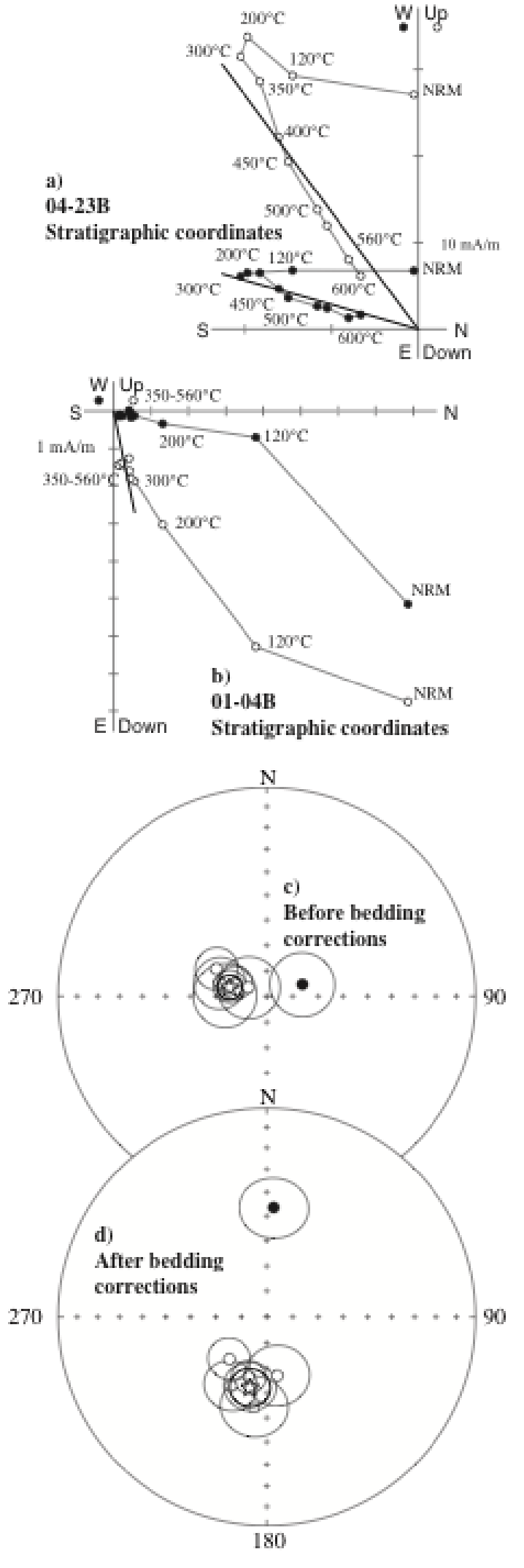

Jimusar (Upper Triassic)

e) 572

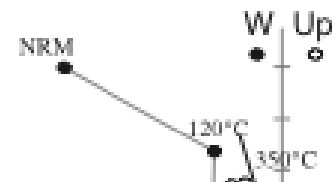

Stratigraphic coordinates $200^{\circ} \mathrm{C}$ o o $450^{\circ} \mathrm{C}$
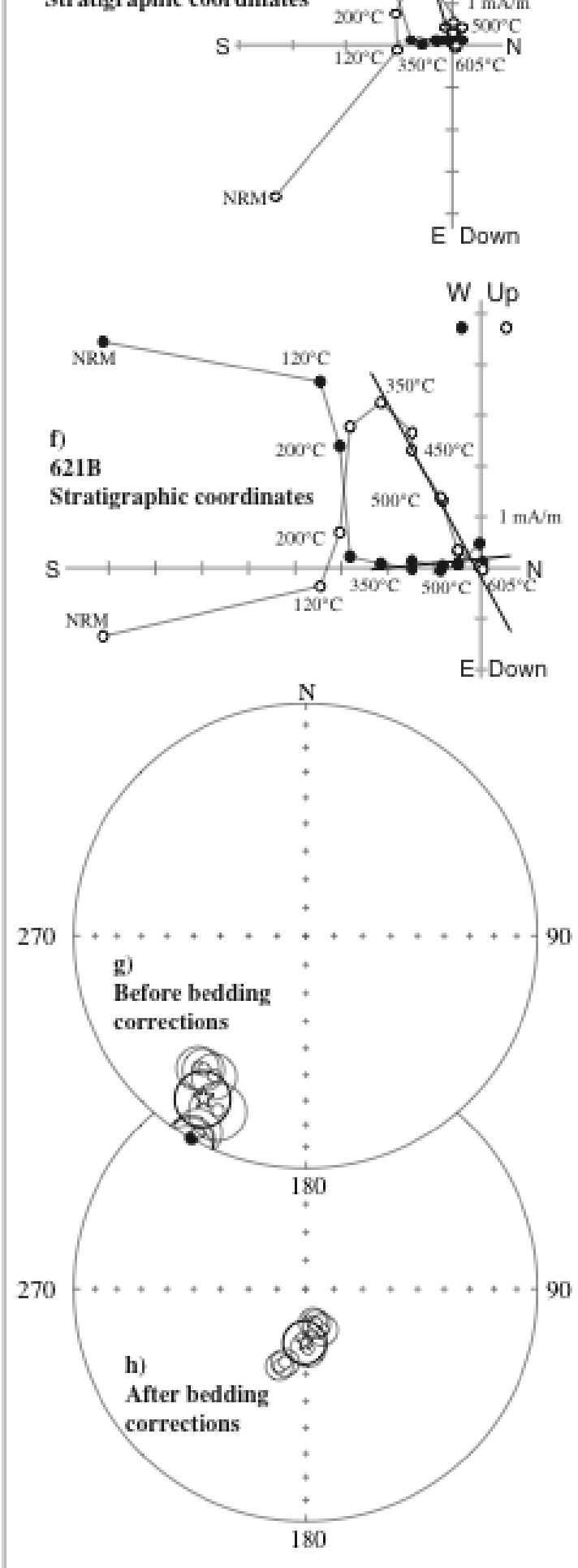

Figure 12 
Aiwergou (Lower Triassic)

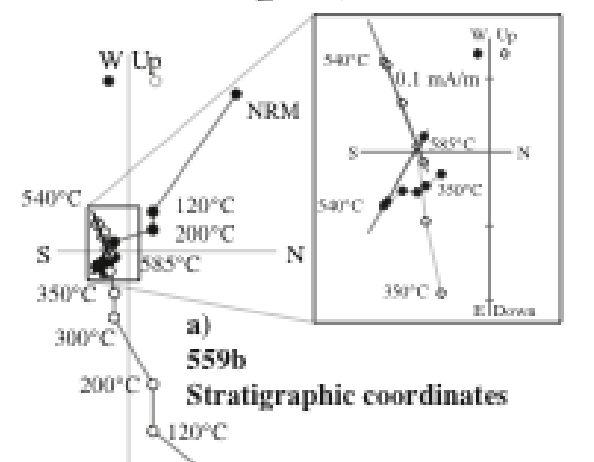

$1 \mathrm{~mA} / \mathrm{m}-{ }_{\mathrm{D}} \mathrm{NRM}$

E Down

c)
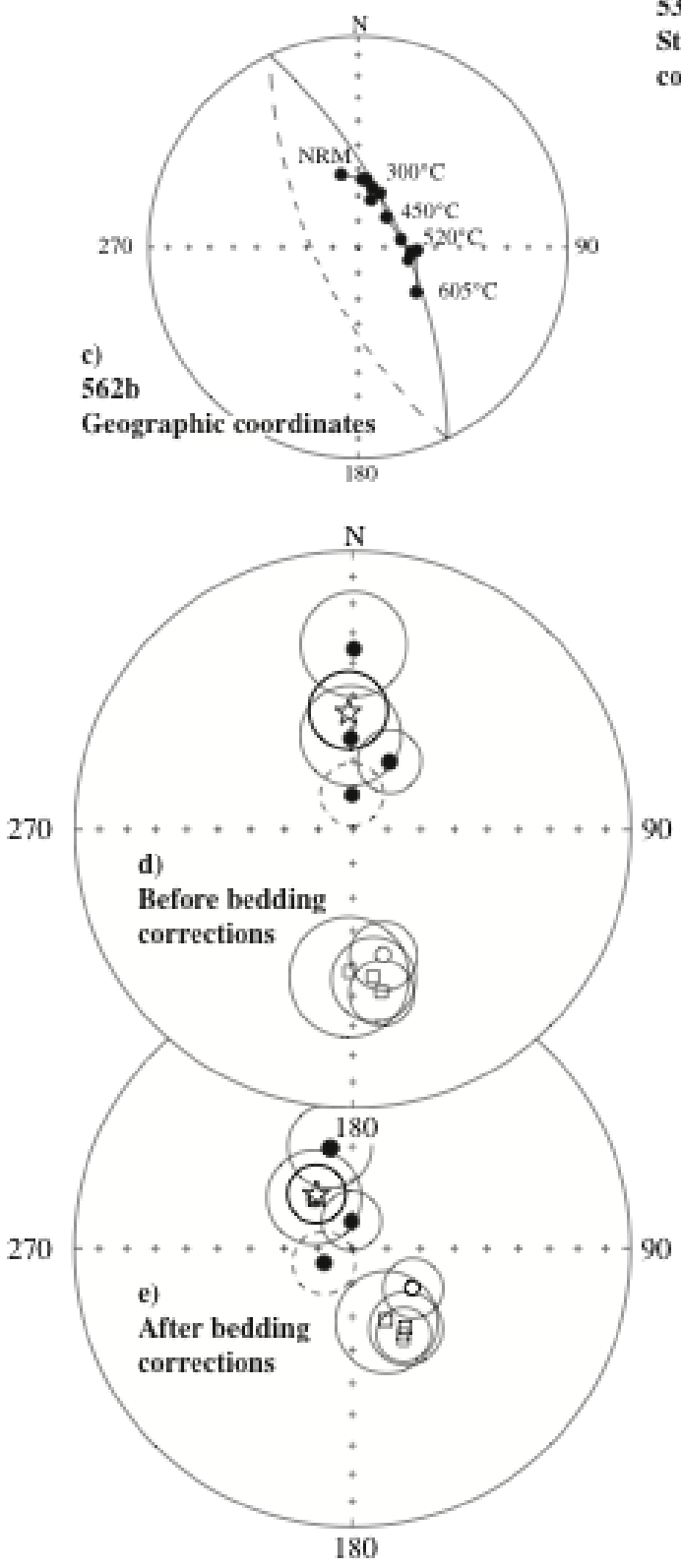

Laba (Lower Triassic)

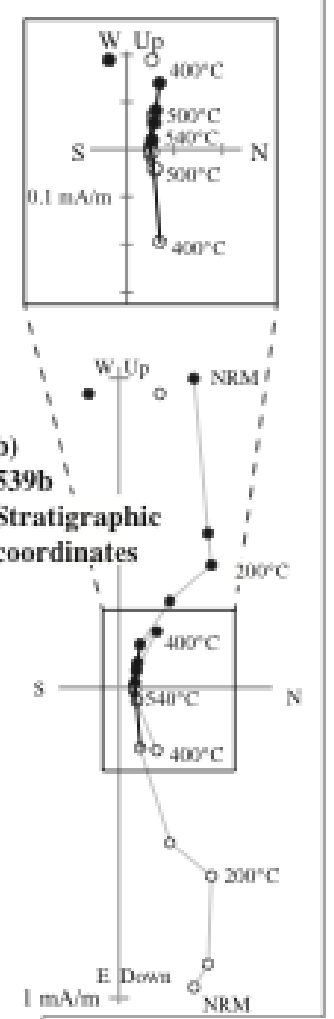

84B

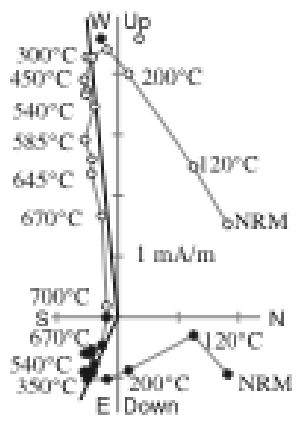

Stratigraphic coordinates

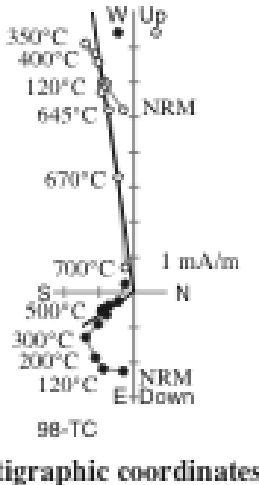

Stratigraphic coordinates

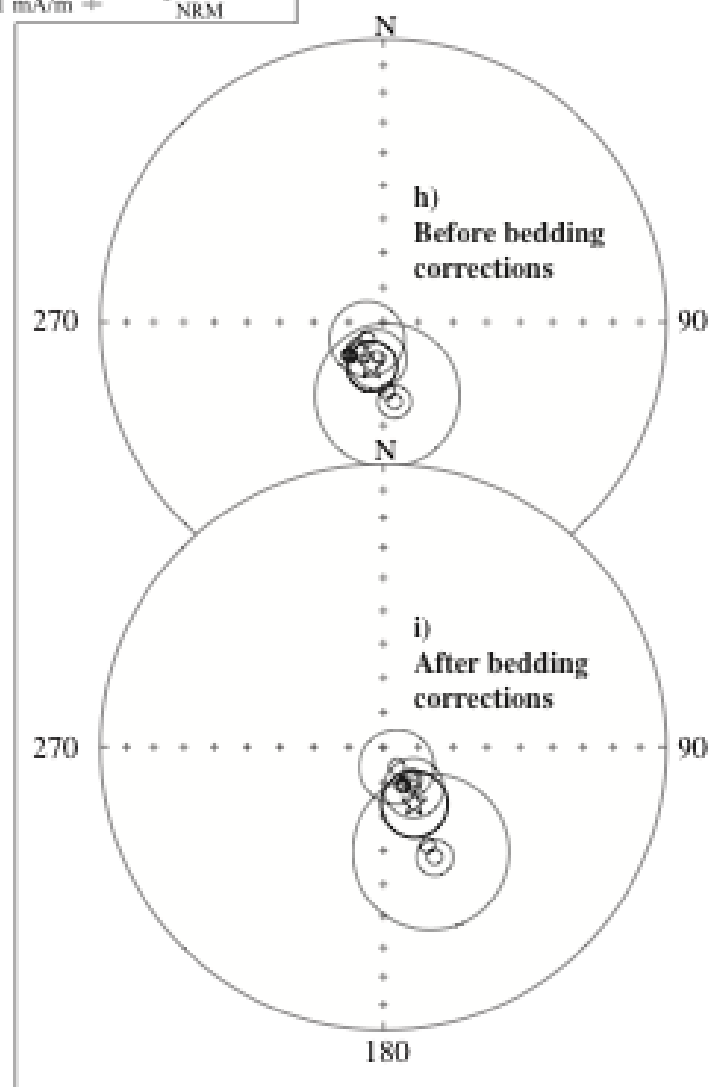

Figure 13 


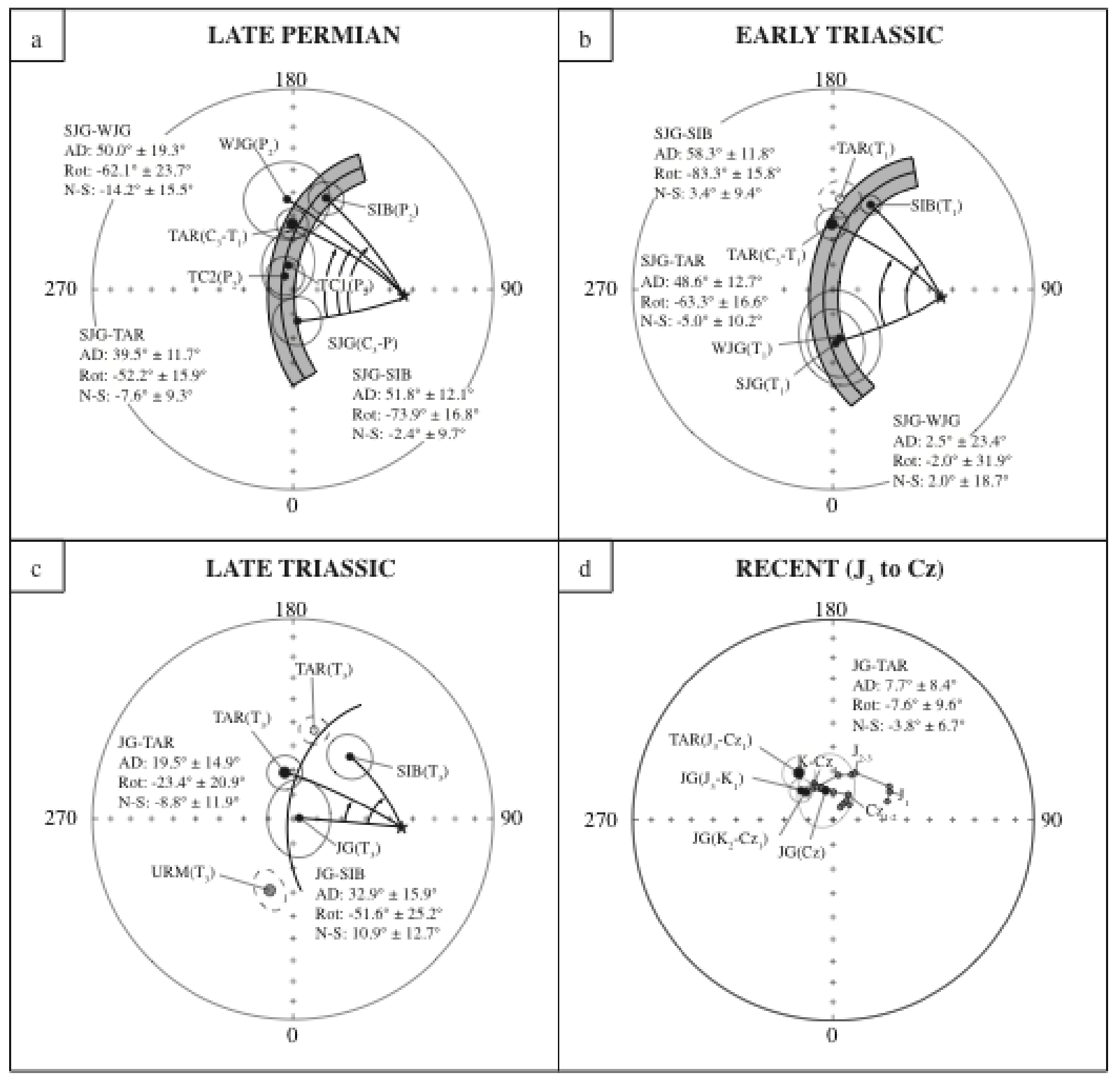

Figure 14 


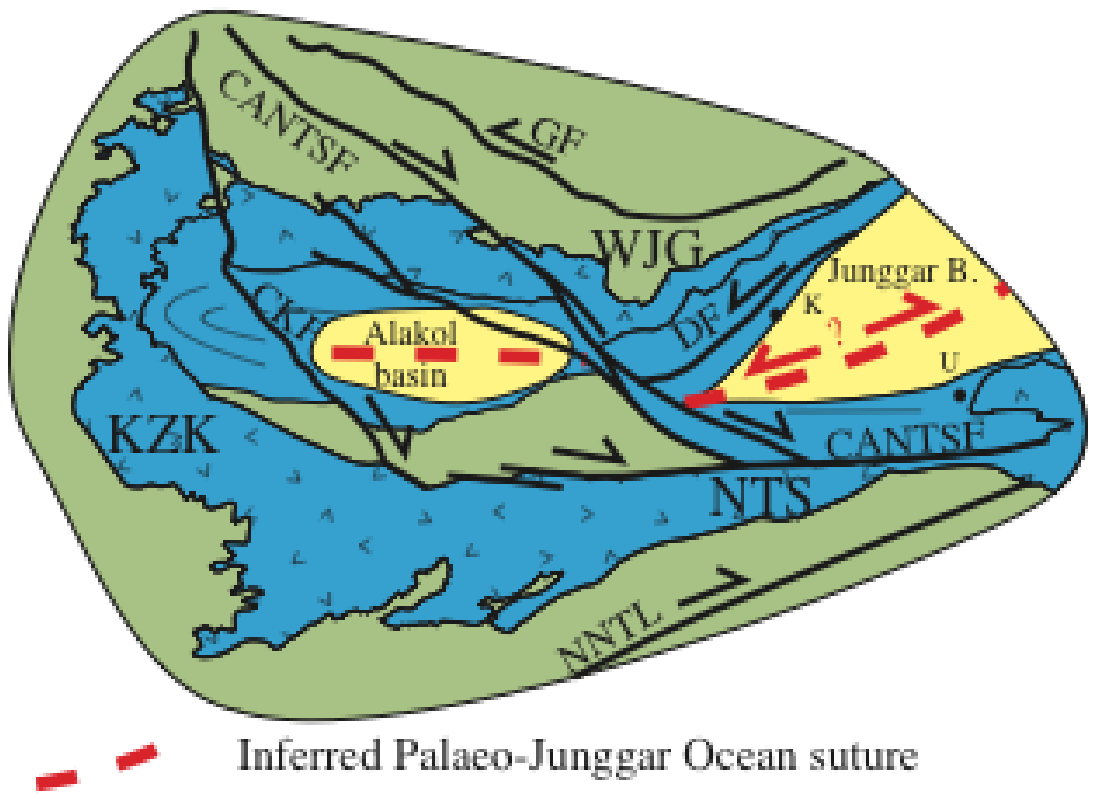

Figure 15 


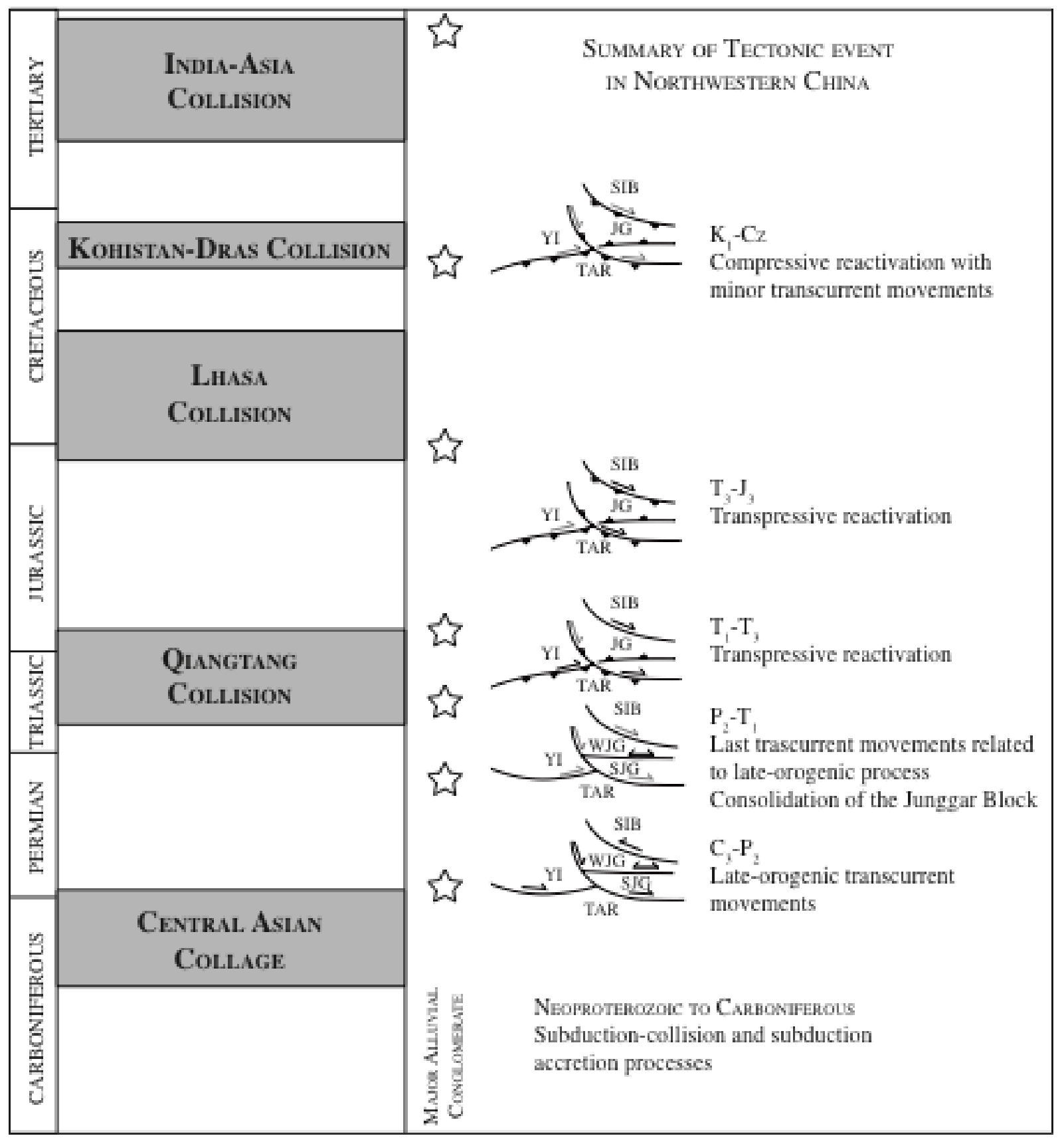

Figure 16 